(C) 2017, THE AUTHORS. Published by FASS and Elsevier Inc. on behalf of the American Dairy Science Association ${ }^{\circledR}$.

This is an open access article under the CC BY-NC-ND license (http://creativecommons.org/licenses/by-nc-nd/3.0/).

\title{
Effect of dietary flax seed and oil on milk yield, gross composition, and fatty acid profile in dairy cows: A meta-analysis and meta-regression
}

\author{
M. Leduc, M.-P. Létourneau-Montminy, R. Gervais, and P. Y. Chouinard ${ }^{1}$ \\ Département des Sciences Animales, Université Laval, Québec, QC, G1V 0A6, Canada
}

\begin{abstract}
Several experiments were conducted over the past few years to evaluate the feeding value of flax seed and oil in dairy cow diets. The current meta-analysis and meta-regression was undertaken to assess the overall effect of different forms of flax, as a source of trienoic (cis-9,cis-12,cis-15 18:3) fatty acids (FA), on lactation performance and on transfer efficiency of its constituent n-3 FA from diet to milk fat. Comparisons were first conducted with nonsupplemented controls or with diets containing either saturated (mainly 16:0 or 18:0 or both), monoenoic (mainly cis-9 18:1), or dienoic (mainly cis-9,cis-12 18:2) FA. Results indicate that supplementing flax seed and oil decreased dry matter intake, as well as actual and energy-corrected milk yield without affecting the efficiency of utilization of dietary dry matter or energy as compared with nonsupplemented iso-energetic controls. When compared with the other 3 types of dietary fat evaluated, flax rich in trienoic FA supported a yield of energy-corrected milk similar to supplements rich in saturated, monoenoic, or dienoic FA. Greater milk fat concentration and feed efficiency were observed with saturated supplements. However, milk fat concentration and yield were lower with dienoic FA than with flax supplements. Further analyses were conducted to compare the effect of different forms of flax oil, seed, or fractions of seed. Among the 6 categories evaluated, mechanically processed whole seed (rolled or ground) allowed the greatest yield of energy-corrected milk and the best feed efficiency when compared with free oil, intact or extruded whole seed, protected flax, and flax hulls. Feeding protected flax and flax hulls allowed the greatest milk fat concentration of cis-9,cis-12,cis-15 18:3. Moreover, the greatest transfer efficiencies of this fatty acid from diet to milk were recorded with the same 2 treatments, plus the mechanically processed whole seed. These results make this last category the most suitable treatment,
\end{abstract}

Received January 24, 2017.

Accepted July 15, 2017.

${ }^{1}$ Corresponding author: Yvan.Chouinard@fsaa.ulaval.ca among the 6 flax forms evaluated, to combine optimum lactation performance and protection of flax constituent cis-9, cis-12, cis-15 18:3.

Key words: linseed, dietary fat, milk composition, fatty acid, $\alpha$-linolenic acid

\section{INTRODUCTION}

Consumption of food products from animals fed flax seed (also called linseed; Linum usitatissimum) as a source of n-3 fatty acids (FA), including milk, has been associated with positive effects on blood lipid profile in humans (Weill et al., 2002; Malpuech-Brugère et al., 2010). Flax oil contains 54 to $55 \%$ - -linolenic acid (cis9,cis-12,cis-15 18:3, INRA-AFZ, 2002; Glasser et al., 2008a) and is therefore a rich source of n-3 PUFA. Intake of flax seed or oil by dairy ruminants has also been shown to mitigate their methane production (Chilliard et al., 2009), improve reproductive performance (Santos et al., 2008; Zachut et al., 2010b), and modulate immune functions (Caroprese et al., 2009, 2016). For these reasons, several experiments were conducted in dairy cows to study the effect of different forms of flax seed and oil, and also to compare their effects with other lipid sources on milk yield and composition. Among several factors evaluated, a specific objective of these experiments was to study the effects on milk FA profile, with a special emphasis on the transfer efficiency of cis-9,cis-12,cis-15 18:3 from diet to milk secretion.

In a meta-analysis, Glasser et al. (2008a) individually compared different oilseeds (flax seed, rapeseed, soybean, and sunflower seed) with nonsupplemented control treatments. However, no direct comparison between these different types of oilseeds was conducted. Similarly, Brunschwig et al. (2010) in a literature review and Sterk et al. (2012) in a meta-analysis compared different forms of technologically processed flax seed and oil to control treatments, but the difference between these varying flax forms was not determined. More recently, Meignan et al. (2017) conducted a meta-analysis to study the effect of extruded flax seed on milk yield and composition. Finally, Petit (2010) published a literature review on the effects of flax seed on feed intake, milk production, and milk composition of dairy cows, 
but differences between processing technics were not assessed statistically.

Strategies to design nonsupplemented control diets may differ in feeding trials conducted to study the effect of different lipid sources, such as flax seed or oil, on animal performance. In several experiments, supplemental fats are added to dairy cow diets at the expense of forage, concentrate, or both on a kilogramfor-kilogram basis, without adjustment for the extra energy provided by the lipid source. Another strategy is to modify the ingredient composition of the control diet, in particular the forage-to-concentrate ratio, with the objective to adjust its energy concentration as compared with the fat-supplemented ration. These different approaches, related to dietary energy supply, may affect the outcomes of the experiment.

Consequently, the current meta-analysis and metaregression was undertaken to assess the effect of flax seed and oil when comparison is made with low-fat control treatments or with diets containing different lipid sources presenting varying levels of unsaturation. A second objective was to compare the effects of different forms of flax seed and oil on milk yield, milk composition, milk FA profile, and on the transfer efficiency of cis-9, cis-12,cis-15 18:3 from diet to milk secretion.

\section{MATERIALS AND METHODS}

\section{Data Collection}

The research of articles was conducted using Google Scholar (Google, Mountain View, CA) for which literature coverage has been assessed by Gehanno et al. (2013). The following key words were used: dairy cows, flaxseed, linseed, FA profile, milk yield, and milk composition. The research was conducted from September 2015 to January 2016, included articles published until December 31, 2015, and was restricted to French and English languages. With each positive result, the "cited by" function was used to find articles that did not contain our key words, but which could possibly be included in the database. One hundred thirteen articles were recorded. Among them, a total of 78 research papers reporting 84 experiments published between 1998 and 2015 (Table 1) met the predetermined selection criteria. These criteria included evidence that (1) paper was peer-reviewed; (2) at least one treatment was supplemented with flax oil, seed, or fractions of seed; (3) the study was conducted on dairy cattle breeds; and (4) milk yield, milk fat percentage, and concentration of cis-9,cis-12,cis-15 18:3 in milk fat were reported. The database contained 294 treatments among which 160 included flax oil, seed, or fractions of seed.
Number of observations, diet composition, as well as production performance and milk composition for 5 different comparisons evaluated in experiments 1 and 2 are reported in Supplemental Tables S1 and S2 (https:// doi.org/10.3168/jds.2017-12637). The composition of experimental rations containing 6 different categories of flax forms is presented along with their respective number of observations in Supplemental Table S3 (https:/ / doi.org/10.3168/jds.2017-12637).

When ether extract (EE) concentration of the ration was the only value available to establish lipid intake, the FA intake was estimated by multiplying the EE concentration by the average FA to EE ratio $(0.760 \pm$ 0.095 ; mean $\pm \mathrm{SD}$ ), calculated from research articles included in the original database where both values were reported $(\mathrm{n}=33)$.

The feed library of the Cornell Net Carbohydrate and Protein System (version 6.6.5, Cornell University, Ithaca, NY) and the INRA-AFZ (2002) tables of feed composition were used to complete the missing FA profile of experimental feed ingredients, as suggested by Mannai et al. (2016). The yield of ECM was calculated as described by Madsen et al. (2008). Metabolizable energy was converted to $\mathrm{NE}_{\mathrm{L}}$ according to NRC (2001).

Total odd-chain FA ( $\mathbf{O C C F A})$, trans octadecenoic acids $(\boldsymbol{\Sigma} \boldsymbol{t} \mathbf{1 8 : 1})$, cis octadecenoic acids $(\boldsymbol{\Sigma} \boldsymbol{c} \mathbf{1 8 : 1})$, and CLA ( $\mathbf{\Sigma C L A})$ were calculated based on the FA in these categories reported within each article. Total de novo synthesized FA ( $\boldsymbol{\Sigma}$ DNFA) included 4:0, 6:0, 8:0, 10:0, 12:0, 14:0, and 14:1. Articles for which major FA of the respective categories were not reported or out of biologically valid ranges were excluded from the analysis.

\section{Data Investigation and Statistical Analysis}

Four different series of statistical analyses were conducted using sub-data sets from the original database. In a first experiment, rations containing dietary supplements of flax oil, seed, or fractions of seed rich in cis-9,cis-12,cis-15 18:3, a trienoic FA (flax-TRI), were compared with nonsupplemented control treatments. In a second experiment, flax-TRI supplements were compared with lipid sources varying in FA composition. In a third experiment, comparisons were established between different forms of flax-TRI supplementations. The fourth experiment was a factorial analysis with the objective to compare the interrelationships within a set of variables of our original database with established theoretical meaningfulness with regards to lipid supplementation and its effect on milk production and composition, as well as milk FA profile. 


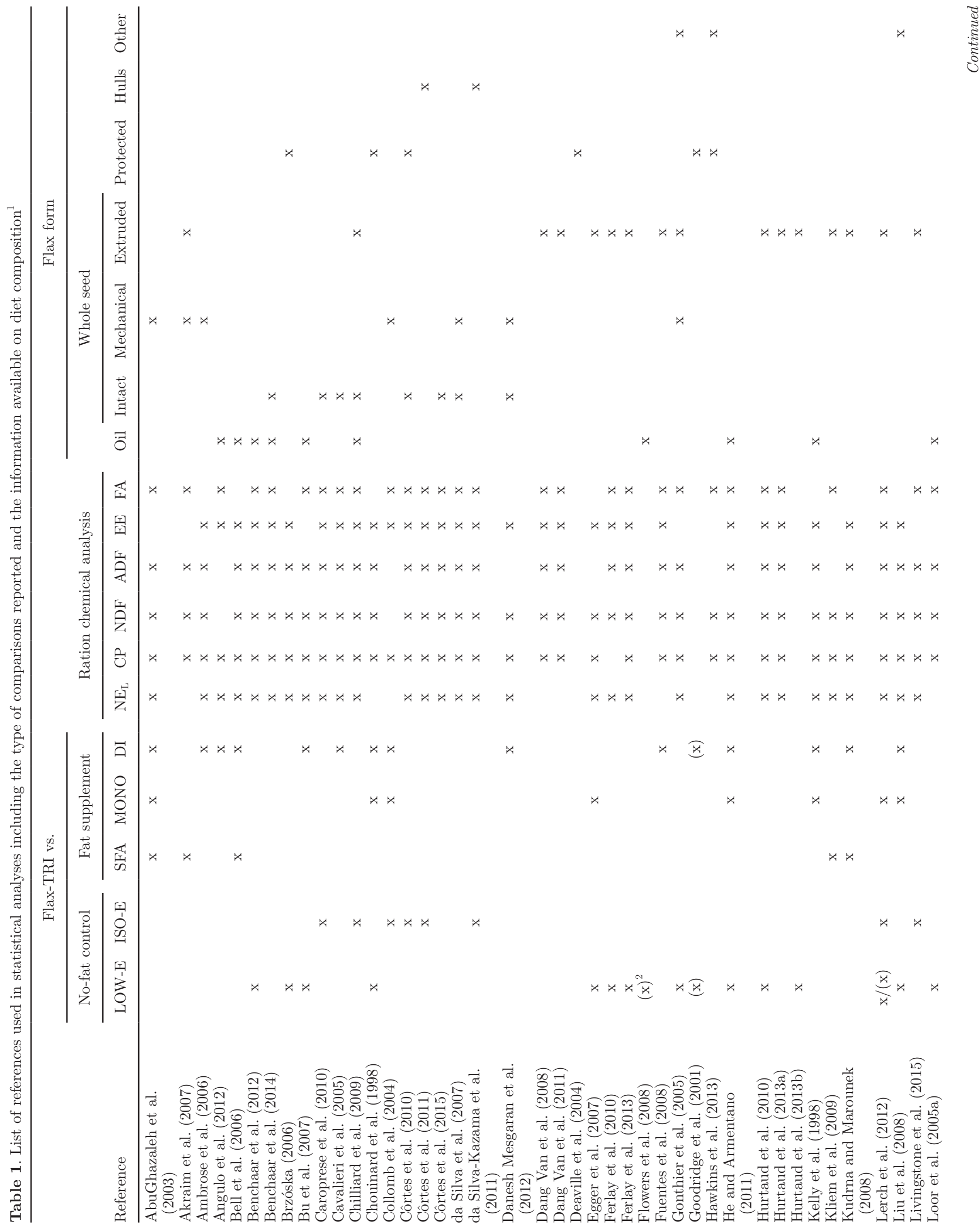




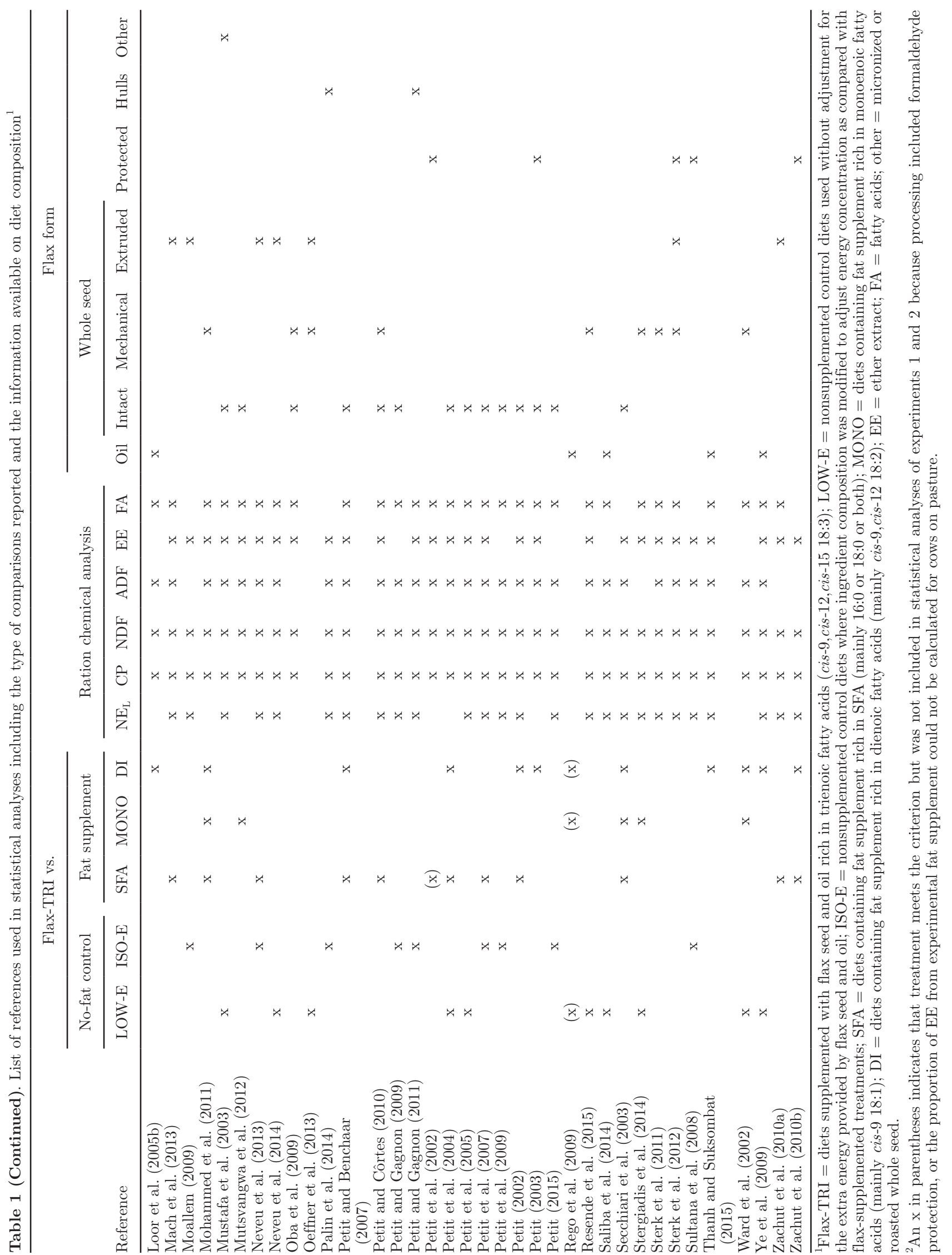




\section{Experiment 1-Flax-TRI vs. Nonsupplemented Control}

To assess the effect of flax-TRI supplements on milk production and composition, a sub database was constituted with the fat-supplemented diets for which the main lipid source was flax oil, seed, or fractions of seed. This sub database also included the nonsupplemented diets, for which treatments were further categorized as low-energy (LOW-E) or iso-energetic (ISO-E) controls. Experiments with a LOW-E control were those where flax lipids were added in the diet at the expense of forages, concentrates, or both, on a kilogram-for-kilogram basis. Experiments with an ISO-E control were those where dietary modifications were made to adjust the concentration of $\mathrm{NE}_{\mathrm{L}}$ between treatments by changing the proportions of dietary ingredients with different energy density (e.g., forage vs. concentrate, starchy vs. fibrous concentrate). The objective of obtaining ISO-E control was considered to be reached when the difference between diets was less than $35 \mathrm{kcal} / \mathrm{kg}$ of DM, which corresponds to the substitution of $1 \%$ vegetable oil for $1 \%$ ground corn, according to NRC (2001). Dietary oil or oilseeds treated with formaldehyde were removed from the model due to superior protection

Table 2. Dietary lipid sources evaluated and number of treatments in each category of supplementation (experiments 1 and 2)

\begin{tabular}{|c|c|c|c|c|}
\hline \multirow[b]{3}{*}{ Lipid source } & \multicolumn{4}{|c|}{ Category $^{1}$} \\
\hline & \multirow[b]{2}{*}{ Flax-TRI } & \multicolumn{3}{|c|}{ Fat supplement } \\
\hline & & SFA & MONO & DI \\
\hline Flax seed or oil & 148 & - & - & - \\
\hline Corn & - & - & - & 1 \\
\hline Cottonseed & - & - & - & 1 \\
\hline Linola & - & - & - & 1 \\
\hline Safflower & - & - & - & 2 \\
\hline Soybean & - & - & - & 10 \\
\hline Sunflower & - & - & - & 14 \\
\hline High-oleic safflower & - & - & 1 & - \\
\hline High-oleic sunflower & - & - & 1 & - \\
\hline Olive & - & - & 1 & - \\
\hline Peanut & - & - & 2 & - \\
\hline Rapeseed & - & - & 15 & - \\
\hline Energy Booster $100^{2}$ & - & 1 & - & - \\
\hline Ca salt of palm & - & 13 & - & - \\
\hline Palm & - & 2 & 1 & - \\
\hline Rumo-fat $^{3}$ & - & 1 & - & - \\
\hline Tallow & - & 1 & - & - \\
\hline Total & 148 & 18 & 21 & 29 \\
\hline
\end{tabular}

${ }^{1}$ Flax-TRI $=$ diets supplemented with flax seed and oil rich in trienoic fatty acids (cis-9,cis-12,cis-15 18:3); SFA = diets containing fat supplement rich in SFA (mainly 16:0 or 18:0 or both); $\mathrm{MONO}=$ diets containing fat supplement rich in monoenoic fatty acids (mainly cis9 18:1); DI = diets containing fat supplement rich in dienoic fatty acids (mainly cis-9, cis-12 18:2).

${ }^{2}$ Milk Specialties Global, Eden Prairie, Minnesota.

${ }^{3}$ Robt Morgan Inc., Paris, Illinois. or inertness in the rumen, as compared with all other treatments, leading to aberrant results.

A random regression was performed, using the MIXED procedure of SAS 9.4 (SAS Institute Inc., Cary, NC), where the dependent variable was the natural logarithm of the response ratio (RR) when flax-TRI was included in the diet, as compared with LOW-E or ISO-E, for all the variables tested. Independent variables were study, as well as linear and quadratic effects of the level of EE coming from the lipid supplementation. Study was included as a random effect according to Sauvant et al. (2008). In each model, the intercept was forced to zero, considering the absence of difference between treatments at a zero level of lipid supplementation. The percentage of change in a variable was estimated by $\left(e^{\mathrm{RR}}-1\right) \times 100 \%$.

Additionally, the proportion of corn silage in the basal diet was included as an independent variable in the model and its interaction with flax-TRI supplement on milk fat concentration and yield was assessed, using the $\mathrm{RR}$ as the independent variable.

Data for which the absolute value of conditional studentized residual was $>3.0$ were considered as outliers and discarded. The normal distribution of residues and the homogeneity of variance were confirmed (Sauvant et al., 2008).

\section{Experiment 2-Flax-TRI vs. Varying Lipid Sources}

To compare the effect of different lipid sources on production performance and milk composition, including milk FA profile, lipid-supplemented diets were extracted from the database (except for treatments involving dietary oil or oilseed treated with formaldehyde). Treatments were regrouped according to the main FA of the lipid source as follows: flax-TRI vs. fat supplements rich in SFA (mainly 16:0 or 18:0 or both), monoenoic FA (mainly cis-9 18:1; MONO), or dienoic FA (mainly cis-9,cis-12 18:2; DI). A list of specific dietary lipid sources and the number of treatments in each category of supplementation is presented in Table 2 .

Comparisons between treatments on production performance, concentration and yield of milk components, and milk FA profile were performed using a mixed model (SAS 9.4, SAS Institute Inc.) including the effects of study (random) and source of dietary lipid supplementation, the general linear and quadratic effects of the level of lipid supplementation, and the effect of interactions between lipid source and the level of lipid supplementation. Variables were kept in the final model when $P \leq 0.05$, except for the source of dietary lipid supplementation, which was automatically included. 
The presence of outliers as well as the normality and homogeneity of the residuals were assessed according to the procedures mentioned previously.

\section{Experiment 3-Effects of Flax Forms}

To compare the effect of different forms of flax on lactation performance and transfer efficiency of cis9,cis-12,cis-15 18:3 from diet to milk fat, treatments for which the lipid source was flax-TRI were extracted from the original database and classified into 6 categories, according to the form of supplementation. The flax-TRI supplements were offered as free oil $(\mathrm{n}=22)$, fraction of the seed (flax hulls; $\mathrm{n}=8$ ), or whole seed. The whole seed category was further divided into 3 subclasses, consisting of diets in which flax was included: (1) as intact untreated seed $(\mathrm{n}=32),(2)$ after a mechanical processing (rolling, $\mathrm{n}=20$; or grinding, $\mathrm{n}=$ 15 ), or (3) following a heat treatment using the extrusion procedure $(\mathrm{n}=43)$. The sixth category included the treatments for which flax seed and oil were submitted to different technologies to protect PUFA against ruminal biohydrogenation, including encapsulation in a SFA matrix $(\mathrm{n}=1)$, treatments with xylose $(\mathrm{n}=3)$ or formaldehyde $(\mathrm{n}=6)$, or the formation of Ca salts of FA $(\mathrm{n}=6)$. Diets supplemented with either roasted ( $\mathrm{n}$ $=2$ ) or micronized $(n=2)$ flax seed were not analyzed as a category due to the limited number of treatments recorded in the original database.

The Wilcoxon nonparametric test (JMP 11, SAS Institute Inc.) was used to compare the 6 different categories of flax-TRI supplementation without study effect.

\section{Experiment 4-Multivariate Factor Analysis}

A sub database was created with variables related to milk production and composition, including FA profile, from all treatments $(\mathrm{n}=294)$ included in the original database. First, missing values of the database were replaced by a multiple $(\mathrm{n}=25)$ imputed value using the Monte Carlo Markov chain method of the MI procedure (SAS 9.4, SAS Institute Inc.). Then, this database was submitted to a factorial analysis, based on the procedure described by Conte et al. (2016). The number of rotated factors included was selected based on an intrinsic value superior to 1 (Kaiser, 1960). Variables with a loading $\geq 0.12$ or $\leq-0.12$ were considered for the interpretation of the factor pattern. This limit value was established based on the following equation (Sokal and Rohlf, 1995):

$$
l=\tanh \left[\frac{1.96}{\sqrt{\mathrm{n}-3}}\right]
$$

where $l=$ limit loading value, $\tanh =$ hyperbolic tangent, and $n=$ number of observations $(n=282)$. The presence of outliers was assessed using the ROBUSTREG procedure and the least trimmed squares option (SAS 9.4, SAS Institute Inc.). Outliers were identified by visual observation of the robust minimum covariance determinant distances.

\section{RESULTS}

\section{Experiment 1-Flax-TRI vs. Nonsupplemented Control}

Flax-TRI vs. LOW-E Control. Increasing the level of EE supplementation from flax-TRI in dairy rations, as compared with LOW-E control (Figure 1A), decreased DMI by $0.8 \%$ per percentage unit (PU) of increase of the EE (DM basis) from the lipid supplement, without affecting milk yield (both actual and energy-corrected) and the production of major milk constituents (fat, protein, and lactose). Feed efficiency was not affected when calculated on a DMI basis, but decreased by $1.0 \%$ per PU of dietary EE supplementation from flax-TRI when calculated on $\mathrm{NE}_{\mathrm{L}}$ basis. Milk fat and protein concentrations were decreased by 0.9 and $0.8 \%$ per PU of dietary EE supplementation from flax-TRI, respectively, whereas lactose concentration was not affected by the level of EE supplementation from flax-TRI to dairy cows as compared with the LOW-E control. Moreover, the effect of flax-TRI supplementation on milk fat concentration $\left(\mathrm{R}^{2}=0.64 ; P\right.$ $<0.01)$ and yield $\left(\mathrm{R}^{2}=0.16 ; P=0.07\right)$ was affected by the composition of basal rations (Figure 2). Indeed, the quadratic response of flax-TRI supplementation on milk fat (concentration and yield) observed, as a proportion of forage represented by corn silage increased, revealed that flax-TRI supplementation has a limited effect on milk fat when corn silage represents less than $50 \%$ of forage. Concentrations of $\Sigma$ DNFA, 16:0, and $\Sigma$ OCFA in milk fat were decreased by 7,9 , and $6 \%$ per PU of dietary EE from flax-TRI (Figure 1B). In contrast, the proportions of 18:0 (+10\%), $\Sigma c$ 18:1 (+8\%), $\Sigma t$ 18:1 $(+22 \%)$, cis-9, cis-12,cis-15 18:3 (+19\%), and $\Sigma$ CLA $(+14 \%)$ increased with each PU of EE supplementation from flax-TRI, whereas milk fat cis-9,cis-12 18:2 was not affected.

Flax-TRI vs. ISO-E Control. When flax-TRI supplementation was compared with ISO-E control rations, DMI, milk yield (both actual and energy-corrected), and the production of fat, protein, and lactose decreased by 1.2 to $2.1 \%$ per PU of dietary EE from the flax-TRI supplement (Figure 1C). Feed efficiency (DMI and $\mathrm{NE}_{\mathrm{L}}$ bases) and milk fat concentration were not affected. Supplemental EE from flax-TRI decreased 

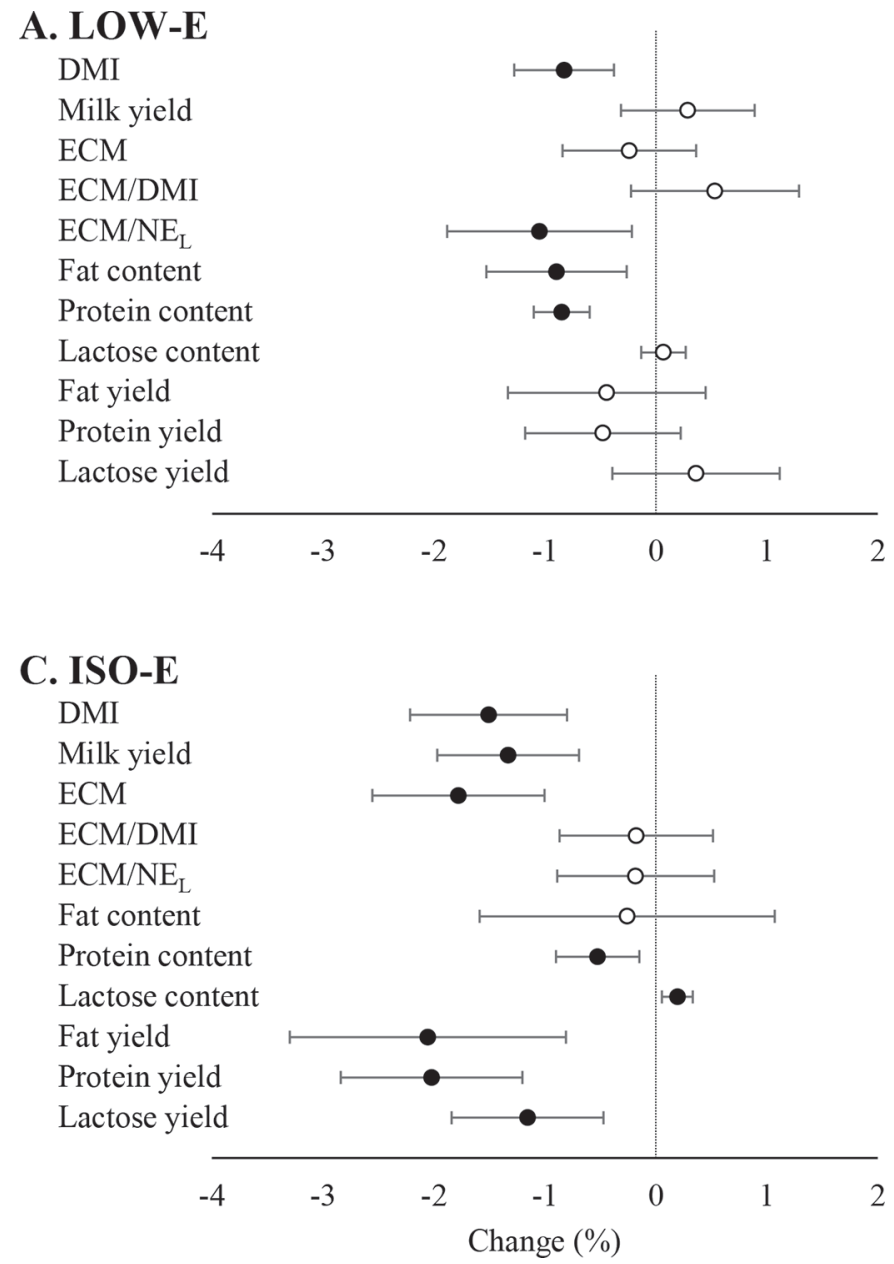

\section{B. LOW-E}

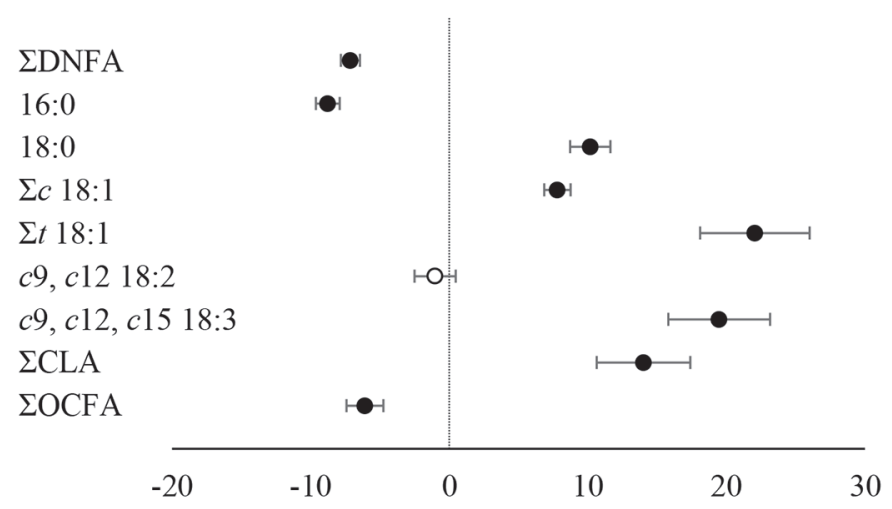

D. ISO-E

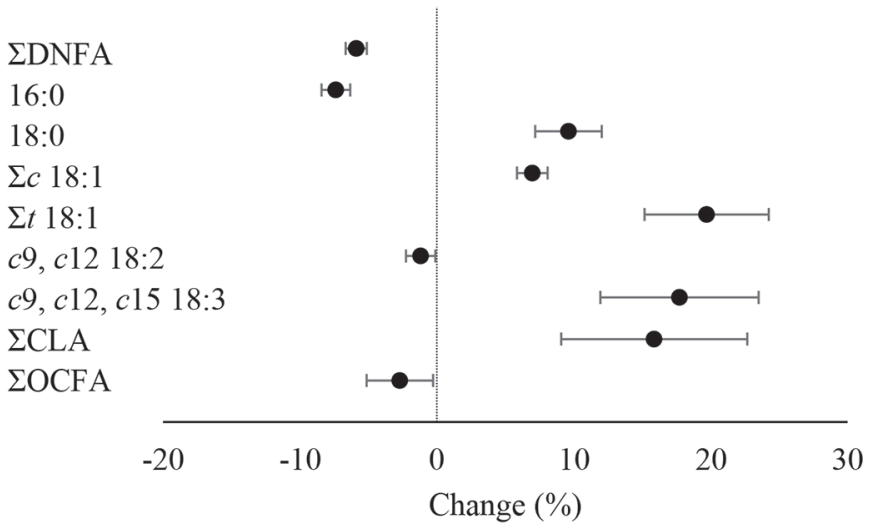

Figure 1. Percent change per unit of increase in dietary ether extract from lipid supplements, expressed as a percentage of DM, in production performance and concentration and yield of milk components (A and C) and individual milk fatty acid concentrations (B and D) when flax seed and oil rich in trienoic fatty acids were included in the diet, as compared with nonsupplemented control treatments adjusted (ISO-E) or not (LOW-E) for dietary energy concentration. Percent change is represented as the mean $\pm 95 \%$ CI. Means represented by solid symbols are statistically different from 0 at $P \leq 0.05 . \Sigma D N F A=$ total de novo synthesized fatty acids $(4: 0+6: 0+8: 0+10: 0+12: 0+14: 0+14: 1)$; $\Sigma c 18: 1=$ total cis octadecenoic acids; $\Sigma t 18: 1=$ total trans octadecenoic acids; $\Sigma$ CLA $=$ total CLA; $\Sigma$ OCFA $=$ total odd-chain fatty acids; $c$ $=$ cis; $t=$ trans.

protein $(-0.5 \%)$, but increased lactose concentrations in milk $(+0.2 \%)$. Regarding milk FA profile (Figure 1D), concentrations of $\Sigma$ DNFA, 16:0, cis-9, cis-12 18:2, and $\Sigma$ OCFA were decreased by $5.9,7.4,1.1$, and $2.7 \%$, respectively, per PU of dietary EE from flax-TRI supplementation. Increases in milk fat concentrations of 18:0 (+9.6\%), $\Sigma c 18: 1$ (+7.0\%), $\Sigma t 18: 1(+19.7 \%)$, cis-9,cis-12,cis-15 18:3 (+17.7\%), and $\Sigma$ CLA (+15.9\%) were observed with every PU of increase in dietary EE from flax-TRI supplementation.

\section{Experiment 2-Flax-TRI vs. Varying Lipid Sources}

Flax-TRI vs. SFA Supplements. No difference was observed between flax-TRI and SFA for DMI; the yields of milk, fat, protein, and lactose; feed efficiency (on DMI and $\mathrm{NE}_{\mathrm{L}}$ bases); and the proportions of cis9,cis-12 18:2 and 5OCFA in milk fat (Table 3). As compared with SFA supplements, feeding flax-TRI decreased feed efficiency (DMI basis), milk fat concentration, and proportion of 16:0 in milk fat. On the contrary, greater concentrations of milk protein and lactose, and greater proportions of $\Sigma c$ 18:1, $\Sigma t$ 18:1, cis-9,cis-12,cis-15 18:3, and ECLA in milk fat were observed with flax-TRI than with SFA supplements. Regardless of source, lipid supplementation increased milk fat concentration of $\Sigma c$ 18:1 (linearly), whereas milk fat concentration varied quadratically. Feeding both lipid sources linearly increased the proportion of 18:0 in milk fat, and the increase was of a greater magnitude with flax-TRI than with SFA (Table 3 and Supplemental Figure S1; https://doi.org/10.3168/jds.2017 

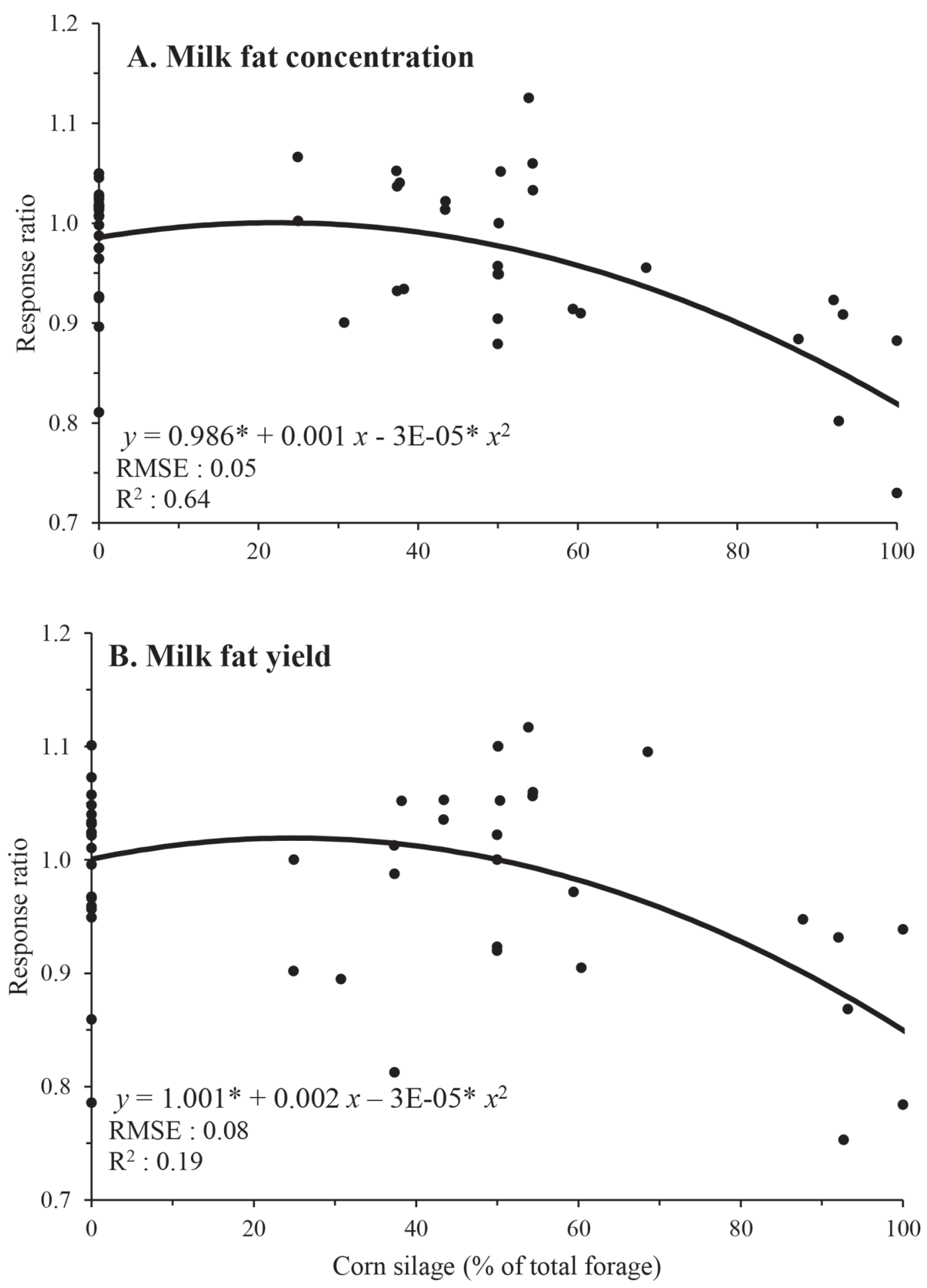

Figure 2. Response ratios for (A) milk fat concentration and (B) milk fat yield in relation to the proportions of corn silage in basal rations when flax seed and oil rich in trienoic fatty acids (cis-9,cis-12,cis-15 18:3) were included in the diet, as compared with nonsupplemented control diets used without adjustment for the extra energy provided by ether extract from flax seed and oil. ${ }^{*} P<0.05$. RMSE $=$ root mean squared error.

-12637). Finally, an interaction between lipid source and the quadratic effect of the level of supplementary EE was observed on the feed efficiency $\left(\mathrm{NE}_{\mathrm{L}}\right.$ basis $)$ and the proportion of $\Sigma$ DNFA in milk fat (Table 3 and Supplemental Figure S1; https://doi.org/10.3168/jds .2017-12637). 
LEDUC ET AL.

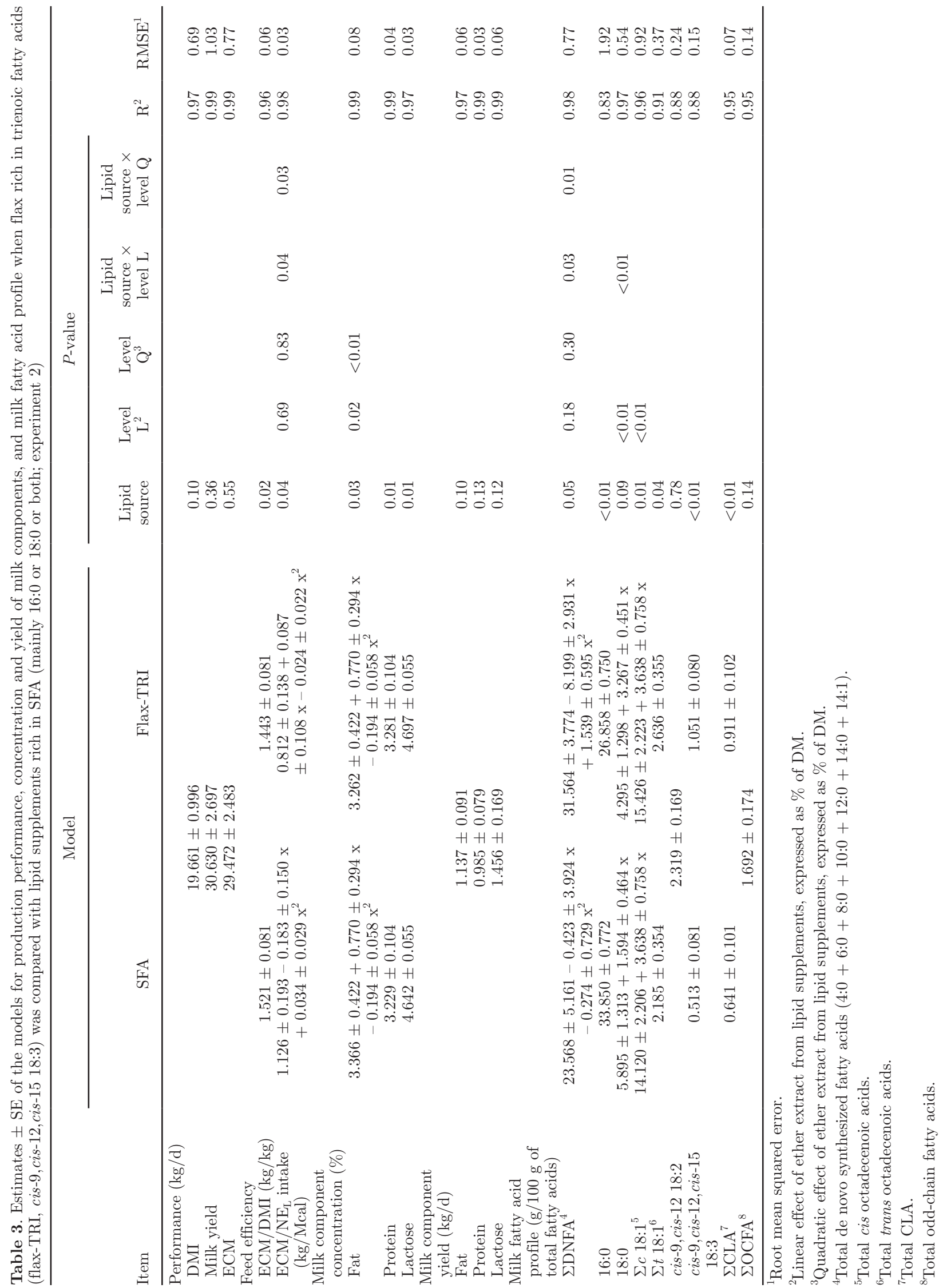


Flax-TRI vs. MONO Supplements. Dietary flax-TRI, as compared with MONO supplements, did not affect DMI, concentrations and yields of milk fat and protein, and proportions of $\Sigma \mathrm{OCFA}$ in milk fat (Table 4). Similarly, milk yield, ECM, feed efficiency $\left(\mathrm{NE}_{\mathrm{L}}\right.$ basis), as well as the proportions of $\Sigma \mathrm{DNFA}$, 18:0, and $\Sigma c$ 18:1 in milk fat, were not affected by lipid source. However, these variables were affected quadratically with the level of dietary EE from both lipid supplements. In milk fat, greater proportions of cis-9,cis-12 18:2 and cis-9,cis-12,cis-15 18:3, but lower proportion of 16:0 were observed with flax-TRI than with MONO supplements. Milk fat concentration of 16:0 also varied quadratically with an increase in dietary lipid supplementation, regardless of source. Lactose yield was not different between lipid supplements, but varied quadratically with the level of lipid supplementation. The concentration of this milk constituent also decreased with the level of EE, the decrease being of greater magnitude with MONO supplements (Table 4 and Supplemental Figure S2; https://doi.org/10 .3168/jds.2017-12637). Significant interactions between lipid source and the level of EE supplementation were also observed with an increase of feed efficiency (DMI basis), and greater increments in the proportions of $\Sigma t$ 18:1 and $\Sigma$ CLA in milk fat with flax-TRI than with MONO (Table 4 and Supplemental Figure S2; https:// doi.org/10.3168/jds.2017-12637).

Flax-TRI vs. DI Supplements. No difference was observed between flax-TRI and DI supplements for DMI, milk yield, ECM, feed efficiency (DMI and $\mathrm{NE}_{\mathrm{L}}$ bases), milk protein concentration and yield, lactose yield, and proportion of 16:0, $\Sigma c$ 18:1, $\Sigma$ CLA, and $\Sigma$ OCFA in milk fat (Table 5). Milk fat concentration and yield were increased by feeding flax-TRI as compared with DI supplements. Cows fed flax-TRI produced milk fat with greater proportions of cis-9, cis12,cis-15 18:3 and EDNFA, but lower proportions of Lt 18:1 and cis-9,cis-12 18:2 as compared with DI supplements. With both lipid sources, milk fat concentrations of $\Sigma c$ 18:1 and $\Sigma$ CLA increased linearly with an increase in supplemental dietary EE. The opposite was observed for milk fat concentrations of $\Sigma$ DNFA and 16:0, whereas $5 \mathrm{OCFA}$ varied quadratically. Finally, a significant interaction was observed between lipid source and the quadratic effect of supplementation level on lactose concentration and proportions of 18:0 in milk fat (Table 5 and Supplemental Figure S3; https://doi.org/10.3168/jds.2017-12637).

\section{Experiment 3-Effects of Flax Forms}

Dry matter intake was similar among the different forms of flax oil, seed, or fractions of seed studied
(Table 6). Actual milk yield was greater for mechanically processed whole flax seed as compared with flax oil, whereas intermediate milk yields were observed with the other 4 flax categories. Feeding mechanically processed flax seed increased the yield of ECM as compared with free oil and flax hulls, as well as intact and extruded whole seed. Intermediate value was observed with protected flax, and the numerically lowest ECM was obtained with free oil. As a result of the effect of treatments on production, the efficiency of ECM yield, expressed both on DMI and $\mathrm{NE}_{\mathrm{L}}$ bases, was improved by feeding mechanically processed whole seed as compared with all other flax forms. Among these remaining categories, feed efficiency was greater for extruded whole seed, lower with flax hulls, and intermediate with free oil, intact whole seed, and protected flax.

Greater milk fat concentration was obtained with mechanically processed as compared with extruded whole seed. Feeding free oil further decreased milk fat concentration as compared with these 2 treatments. Intermediate milk fat concentrations were obtained with intact whole seed, protected flax, and flax hulls. Similar results were obtained for milk fat yield, except that no difference was observed between intact or extruded whole seed. Milk protein concentration was greater with free oil, protected flax, and flax hulls when compared with extruded whole seed, whereas intermediate values were observed with intact or mechanically processed whole seed. Feeding mechanically processed seed increased milk protein yield as compared with free oil or intact whole seed, whereas intermediate values were associated with extruded whole seed, protected flax, or flax hulls.

Milk fat concentration of 16:0 was lower with free oil, intermediate with flax hulls, and greater with intact, mechanically treated, or extruded whole seed, as well as protected flax. Greater milk fat concentration of $\Sigma t$ 18:1 was obtained with free oil followed by extruded whole seed then mechanically processed whole seed. Feeding intact whole seed and protected flax further decreased the concentration of $\Sigma t 18: 1$ as compared with these former 3 treatments. Average concentration of $\Sigma t$ 18:1 observed with flax hulls only differed statistically $(P<0.05)$ with free oil treatment. The proportion of $\Sigma$ CLA in milk fat was greater with free oil as compared with extruded whole seed and protected flax, whereas intermediate values between these treatments were observed with flax hulls. Feeding mechanically processed and then intact whole seed further decreased the concentration of $\Sigma$ CLA as compared with these 4 treatment categories.

Protected seed and flax hulls are the forms of lipid supplement associated with the highest milk fat concentrations of cis-9,cis-12,cis-15 18:3. In contrast, the 
LEDUC ET AL.

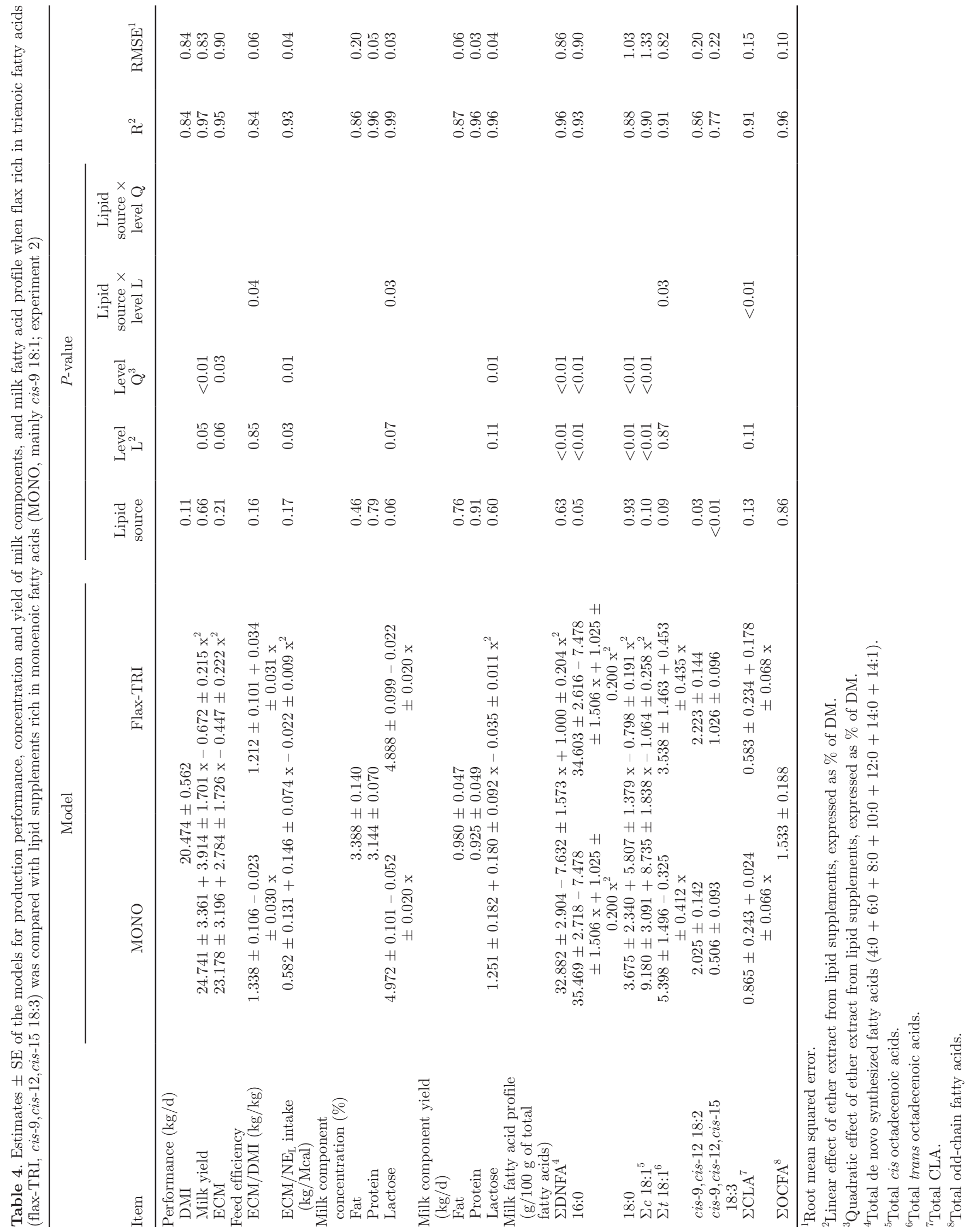


FLAX SEED AND OIL AND LACTATION PERFORMANCE

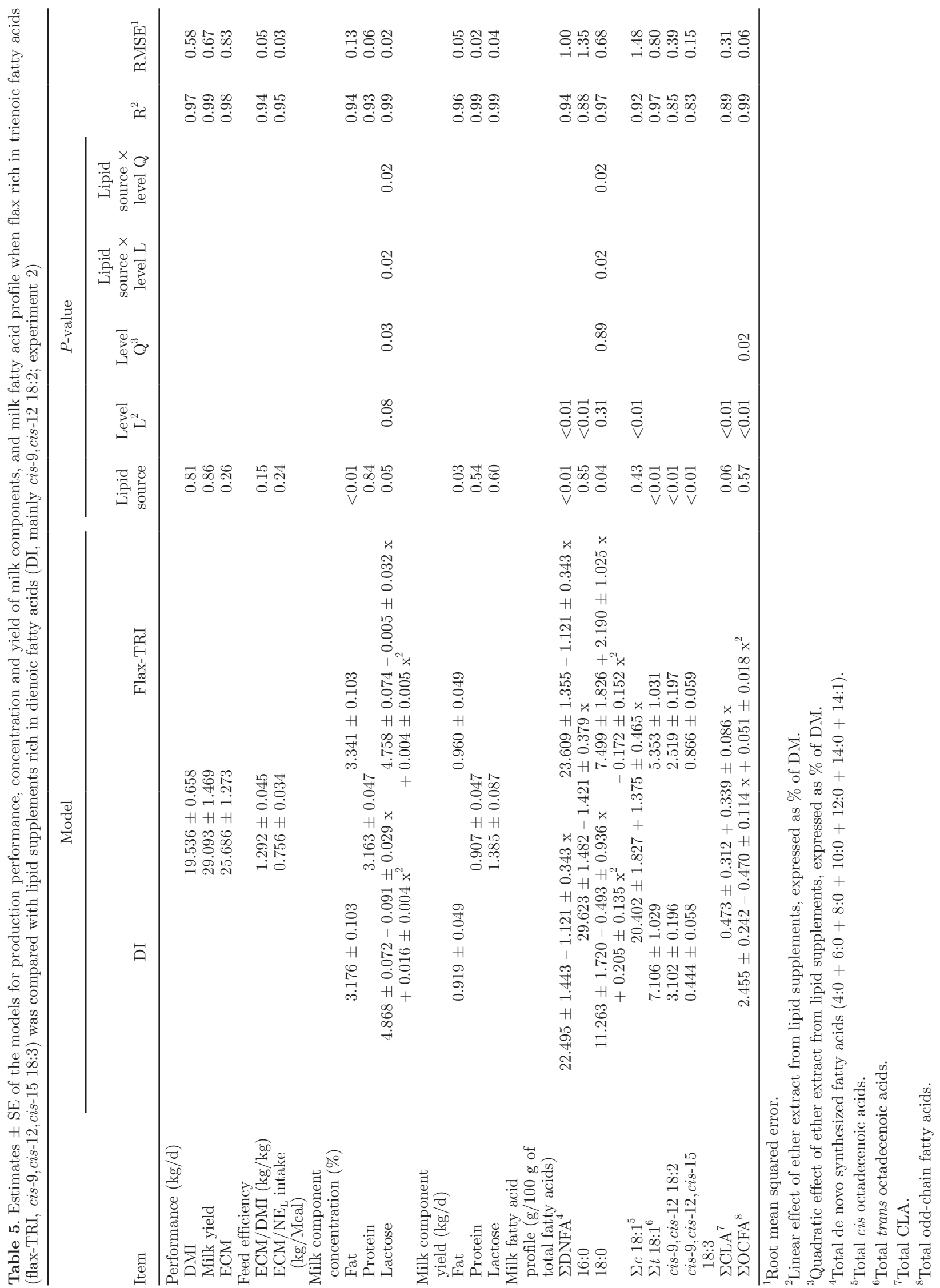


LEDUC ET AL.

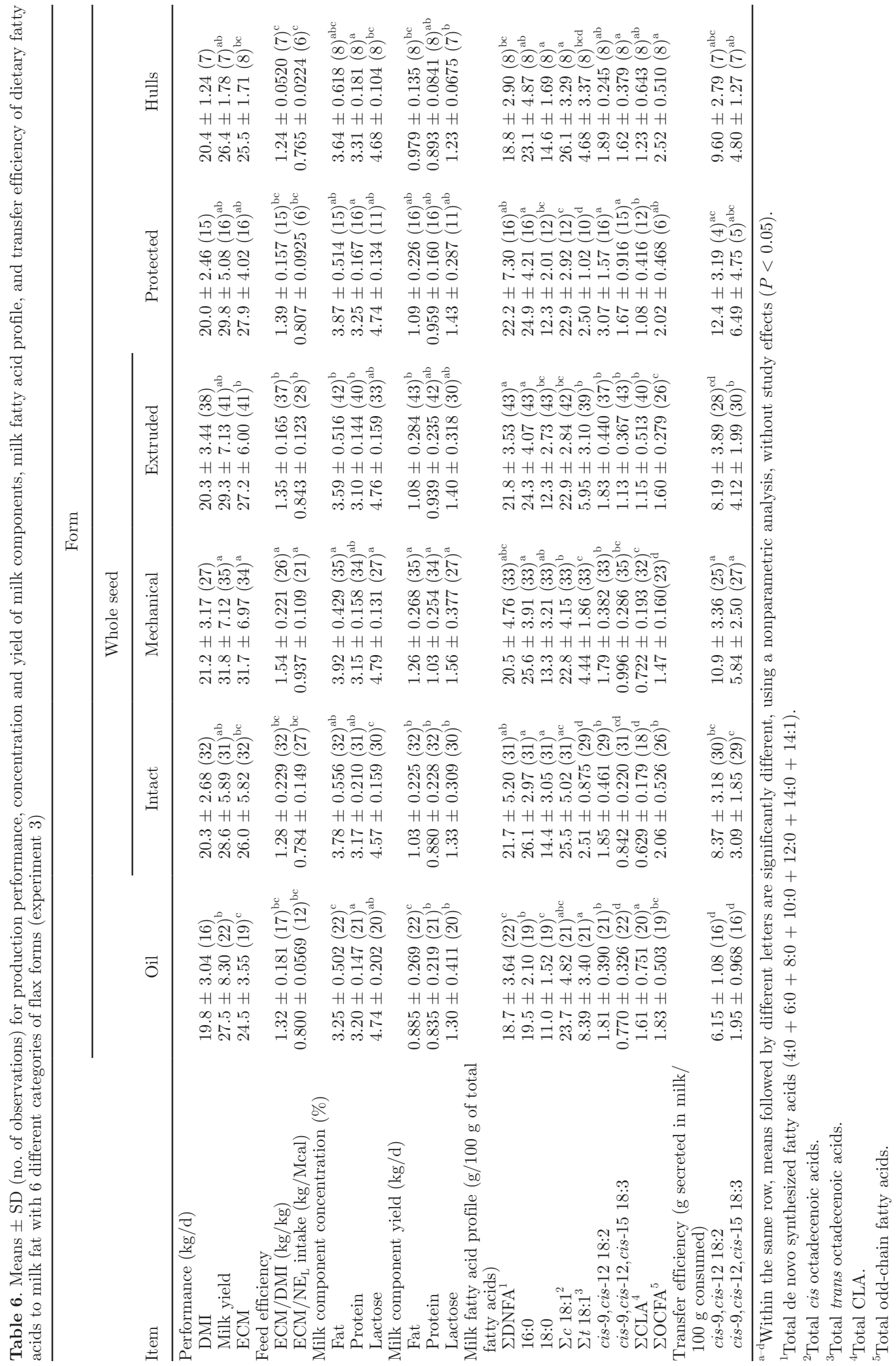


lowest concentration of this milk FA was observed when cows received free oil. Among the other 3 categories in between, lower milk fat concentration of cis-9, cis12,cis-15 18:3 was obtained with intact as compared with extruded whole seed, whereas intermediate value was observed with mechanically processed whole seed. The least efficient transfer of cis-9,cis-12,cis-15 18:3 from diet to milk fat was observed when feeding free oil. Among the remaining categories, the transfer efficiency of cis-9,cis-12,cis-15 18:3 was lower for intact and then extruded whole seed as compared with mechanically processed whole seed. Intermediary efficiencies between these latter 2 treatments were obtained with flax hulls. Average efficiency calculated with protected flax $(\mathrm{n}=$ $5)$ did not statistically differ $(P>0.05)$ from any of the latter 4 categories.

\section{Experiment 4-Multivariate Factor Analysis}

Five principal components (PC) were identified, which explained $75.5 \%$ of the variation (Table 7). Milk fat concentration and yield, milk protein concentration, as well as short- and medium-chain FA (8:0, 10:0, 12:0, and 14:0, 14:1, and 16:0) were positively correlated with the PC 1, which explained $32.3 \%$ of the variability (Table 7 and Supplemental Figure S4; https://doi.org/ 10.3168/jds.2017-12637). Negative associations were observed for the same PC with proportions of milk 18:0, $\Sigma c$ 18:1, $\Sigma t$ 18:1, cis-9,cis-12 18:2, and $\Sigma$ CLA. The second PC (15.9\% of the variability) was related in its positive part with the yields of milk, fat, and protein, as well as proportions of milk 12:0 and cis-9,cis-12 18:2; but in its negative part with concentrations of milk fat and protein, and proportions of milk $\Sigma c 18: 1$ and $\Sigma$ CLA. The PC 3 (12.5\% of the variability) revealed positive associations with proportions of milk $\Sigma t 18: 1$, cis-9,cis-12,cis-15 18:3, and ECLA, but negative associations with milk fat concentration and yield, as well as proportions of milk 8:0, 10:0, 12:0, 14:0, 16:0 18:0, and $\Sigma c$ 18:1. Milk yield, milk protein concentration and yield, and proportions of milk 14:1, 16:0, 16:1, $\Sigma c$ 18:1, and cis-9,cis-12 18:2 were positively correlated with PC 4 (8.0\% of the variability), whereas milk fat concentration and proportions of milk 18:0 and $\Sigma t$ 18:1 were negatively correlated. Finally, the PC5 (6.8\% of the variability) consisted of milk fat concentration and proportions of milk 8:0, 10:0, 18:0 $\Sigma c$ 18:1, cis9,cis-12 18:2, cis-9,cis-12,cis-15 18:3, and ECLA with positive loading values, whereas proportions of milk

Table 7. Common factor loading and communalities for milk yield and composition and milk fatty acid profile (experiment 4)

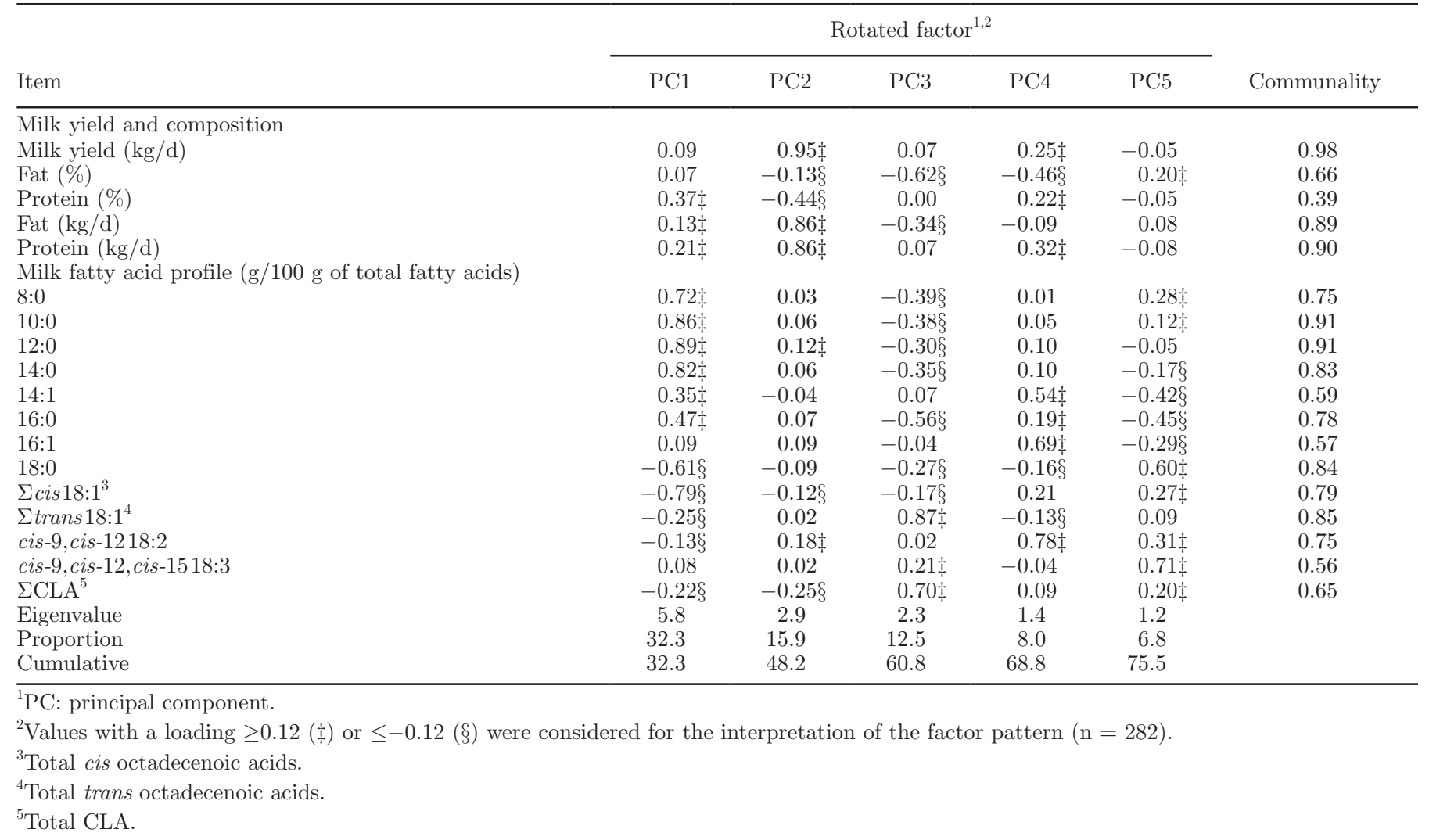


14:0, 14:1, 16:0, and 16:1 were associated with negative loading values.

\section{DISCUSSION}

\section{Experiments 1 and 2-Flax-TRI vs. Nonsupplemented Control or Varying Lipid Sources}

Dietary fat supplements have been shown to reduce DMI through different mechanisms (Allen, 2000). The negative effect of flax-TRI supplementation exposed by the current meta-analysis when compared with LOW-E and ISO-E controls is in line with previous experiments where fat supplementation resulted in a decrease in DMI by reducing feed fermentability and digestibility (Palmquist and Jenkins, 1980). In addition to the effects of dietary lipids on rumen fermentation, Drackley et al. (1992) demonstrated, using postruminal infusion of UFA, a hypophagic effect of lipids. Moreover, Glasser et al. (2008b), in a meta-analysis, observed a linear within-experiment decrease in DMI with increasing duodenal flow of C18 FA (mean slope of $-1.7 \pm$ $0.5 \mathrm{~g}$ of DMI per gram of duodenal C18 increase). It was also proposed by Bradford et al. (2008) that an increase in plasma glucagon-like peptide- 1 and cholecystokinin, with a possible decrease in pre-meal ghrelin, could be involved in the reduction of DMI when PUFA are added to the diets of dairy cows. It is not known, however, whether postruminal supplies of PUFA were enough to cause a hypophagic effect in cows receiving flax seed or oil for experiments included in the current meta-analysis.

One of the main differences observed when flax-TRI supplements were studied in relation to nonsupplemented diets was a decrease in milk production as well as fat, protein, and lactose yields when compared with ISO-E, which was not apparent when the comparison was made with LOW-E controls. Importantly, feed efficiency, calculated on a $\mathrm{NE}_{\mathrm{L}}$ basis, was decreased by flax-TRI diets as compared with the LOW-E control, which means that the extra energy provided by supplemental EE was used less efficiently than other dietary components to produce milk.

Assessing the effect of dietary treatments on lactation performance requires considering the variations in concentrations of major milk constituents. In the current analysis, cows receiving SFA produced milk with greater fat concentrations as compared with flaxTRI supplements. Diets in the SFA category contained greater levels of 16:0 (Supplemental Table S1; https:// doi.org/10.3168/jds.2017-12637). In this regard, Mannai et al. (2016) have shown that the level of dietary 16:0 is positively associated with milk fat concentra- tion. Moreover, SFA are known to have a minimal effect on the rumen fermentation (Jenkins, 1993) and to be more efficiently used by animal tissues, including the mammary gland (Moore and Christie, 1979). This may explain the increased efficiency of milk ECM production, on a DMI basis, in cows fed SFA as compared with flax-TRI supplements.

On the contrary, milk fat depression (MFD) is often associated with feeding unsaturated lipid supplements in dairy cows (He and Armentano, 2011; Mannai et al., 2016). Accordingly, in the current analysis, cows receiving flax-TRI produced milk with lower fat concentrations compared with the LOW-E control. Under these conditions, lower milk fat concentration can be explained by a disturbance in ruminal fermentation causing a shift from the trans-11 to the trans-10 pathway of cis-9,cis-12 18:2 biohydrogenation, leading to the production of trans-10,cis-12 18:2. This CLA isomer has been shown to decrease the expression of lipogenic enzymes and reduce milk fat synthesis in the mammary gland (Bauman and Griinari, 2003). Moreover, other FA isomers are known to induce an anti-lipogenic effect in the mammary gland. For example, trans-9, cis-11 18:2, which is a ruminal biohydrogenation intermediate produced from cis-9,cis-12,cis-15 18:3, seems to be also involved in MFD (Shingfield et al., 2010). Ruminal disturbance caused by dietary PUFA could be exacerbated by increasing the proportions of corn silage in rations. In this regard, a meta-analysis by Meignan et al. (2017) revealed that milk fat concentration and yield decreased when extruded flax seed was supplemented to diets with high proportions of corn silage in the forage but did not decrease when the diet contained alfalfa hay. In the current meta-analysis, the quadratic decrease in milk fat concentration and yield observed when supplementing flax-TRI in diets containing increasing proportions of corn silage confirms this interaction between forage type and fat supplementation.

Also, in the present analysis, the decrease in milk fat concentration associated with lipid supplementation was affected by the degree of unsaturation of dietary 18-carbon FA. Indeed, milk fat concentrations were similar between flax-TRI and MONO supplements, but were decreased by feeding DI lipid sources as compared with flax-TRI. The production of FA intermediates of the trans-10 pathway has been reported during the biohydrogenation of cis-9 18:1 (main FA in MONO; Mosley et al., 2002) and cis-9,cis-12,cis-15 18:3 (main FA in flax-TRI; Lee and Jenkins, 2011). However, as opposed to dietary cis-9,cis-12 18:2, no significant amounts of trans-10,cis-12 18:2 appear to be directly produced during ruminal biohydrogenation of cis9 18:1 and cis-9,cis-12,cis-15 18:3. Although milk fat 
concentration of trans-10,cis-12 18:2 was not assessed in the current meta-analysis, these previous observations could explain the similar milk fat concentration and yield observed with MONO and flax-TRI supplements, but the lower milk fat concentration and yield observed with DI supplements.

In the current analysis, a decrease in milk protein percentage was observed when flax-TRI was compared with LOW-E and ISO-E nonsupplemented controls. Several mechanisms were proposed to explain the protein-depressing effects of dietary fat (DePeters and Cant, 1992). Among them is a dilution effect due to an increased milk yield following fat supplementation. This mode of action is not likely to be applicable in the current analysis as actual milk yield was either not affected (vs. LOW-E) or decreased (vs. ISO-E) with flax-TRI. Another mechanism is that inclusion of lipids in the ration tends to reduce rumen bacterial protein synthesis through a direct inhibiting effect on microbial growth or a reduction of fermentable substrate when fat replaces starch in the diet (Palmquist et al., 1993b). The supply of AA for protein synthesis in the mammary gland would consequently be limited. Other authors also suggested that postabsorption hormonal regulations involving insulin or growth hormone might also be implicated (Doreau and Chilliard, 1992). Wu and Huber (1994) further reported that milk protein depression occurs regardless of the type of fat and at different levels of supplementation. This observation is in line with the lack of difference in milk protein concentration and yield when flax-TRI was compared with MONO and DI supplements. The greater milk protein content observed when cows received flax-TRI as compared with SFA supplements, which are less likely to affect ruminal fermentation, constitutes an exception in this regard.

As expected, feeding flax-TRI increased milk fat concentration of cis-9,cis-12,cis-15 18:3 for all comparisons reported (i.e., vs. LOW-E, ISO-E, SFA, MONO, or DI). Several health benefits are potentially attributed to the consumption of this FA (Cunnane, 2003). As milk fat is a common component of the human diet, enrichment of dairy products with cis-9,cis-12,cis-15 18:3 provides the opportunity to increase intake of this essential FA by the general population.

As also expected, feeding DI supplements increased the concentration of cis-9,cis-12 18:2 in milk fat as compared with flax-TRI. Less expectedly, the increase in the level of 18:0 was of greater magnitude with flaxTRI than with SFA lipid sources, despite the fact that the concentration of this FA was 2.7 times greater in SFA than in flax-TRI supplements (Supplemental Table S1; https://doi.org/10.3168/jds.2017-12637). It appears from this result that flax cis-9,cis-12,cis-15 18:3 was efficiently biohydrogenated to 18:0 in the rumen. After absorption, 18:0 is converted to cis-9 18:1 through the action of $\Delta^{9}$-desaturase (Palmquist et al., 1993a). This reaction may explain the lack of difference in milk fat proportions of $\Sigma c$ 18:1 between flax-TRI and MONO supplements.

The concentrations of $\Sigma$ DNFA and 16:0 in milk fat were decreased by lipid supplementation. It has been known for a while that increasing the uptake of preformed FA from dietary origin by the mammary gland is reducing de novo synthesis of FA, and consequently the concentration of $\mathrm{DDNFA}$ and 16:0 in milk fat (Palmquist and Jenkins, 1980). An exception is observed with the SFA category, which contained several supplements of mainly 16:0, leading to greater concentrations of this FA in milk fat as compared with flax-TRI treatments.

Most of the odd-chain fatty acids (OCFA) secreted in milk fat are known to be of microbial origin (Vlaeminck et al., 2006). Monitoring the concentrations of these FA in milk secretion has then been suggested as a noninvasive tool to evaluate the conditions of ruminal fermentation (Vlaeminck et al., 2006). A negative effect of lipid supplementation on milk $\Sigma$ OCFA was observed when flax-TRI was compared with either LOW-E or ISO-E controls, implicating adverse effects on rumen conditions, and more specifically on the growth of ruminal microorganisms responsible for the synthesis of these FA. Considering that ruminal concentration of propionate, the major precursor of OCFA, is not a limiting factor (French et al., 2012), dietary lipids seem to exert their effects through a reduced bacterial growth in the rumen either by a direct toxicity or by decreasing nutrient availability (Bauchart et al., 1990), leading to a lower concentration of OCFA in milk.

\section{Experiment 3-Effects of Flax Forms}

Current literature comparing different forms of flax seed and oil is limited to a few animal trials (comparison of 2 forms: $\mathrm{n}=11$, or 3 forms: $\mathrm{n}=3$, out of a total of 84 experiments in the database). Considering the paucity of direct within-experiment comparisons, a nonparametric analysis was conducted, in which the effect of study was not considered. In the current analysis, the choice of an optimal technological processing applied to flax seed and oil was based on lactation performance and milk FA profile, with a focus on the transfer efficiency of cis-9,cis-12,cis-15 18:3 from diet to milk fat.

Concerning animal performance, the greatest yield of ECM and the best feed efficiency were obtained with 
mechanically processed whole seed. Lower than what was observed with mechanically processed whole seed, milk yield and feed efficiency were similar among the 5 other form categories. Regarding milk FA profile, the greatest concentrations of cis-9,cis-12,cis-15 18:3 were observed when feeding protected flax and flax hulls. Moreover, the greatest transfer efficiencies of this FA from diet to milk were recorded with the same 2 treatments, plus the mechanically processed whole seed. These values were expected for protected flax, as the category was created based on this specific objective. It should be pointed out that the category of protected flax is heterogeneous, as it regroups several technologies. Among them, 6 experimental diets in the database were designed to test formaldehyde-treated flax seed or oil, which is known to provide a superior protection. The low numbers of treatment diets testing different protection technologies did not allow individual assessment of their effects on milk yield and composition in the current data analysis. The high level of cis-9, cis12,cis-15 18:3 in milk fat, obtained when feeding flax hulls, suggests that residual PUFA in this flax byproduct are partially protected against ruminal biohydrogenation. Indeed, different methods are used in the separation of flax hulls from the whole seed, and even if oil is concentrated in the kernel and embryo fraction, flax hulls still contain an appreciable amount of fat ( $>25 \%$; Hosseinian and Beta, 2009). However, it should be underlined that this observation is based on the evaluation of a lower number of treatment means $(\mathrm{n}=$ 8) as compared with other form categories. In contrast, low transfer efficiencies and milk concentrations of cis9,cis-12,cis-15 18:3 were observed when cows received free oil and intact whole seed. On the one hand, feeding free oil offers no protection of dietary PUFA against ruminal biohydrogenation, which reduces their transfer to milk secretion. These observations are in accordance with Glasser et al. (2008a). On the other hand, dietary PUFA, as part of intact whole seed, although protected in the rumen, appears to be less available for absorption in the small intestine, thus leading to low transfer efficiency from diet to milk. Mechanical processing seems to offer a compromise between these 2 treatments, with a better balance between ruminal protection, and availability for intestinal absorption of dietary PUFA. In line with these observations, intermediate levels of $\Sigma t$ 18:1 were observed in milk when cows were fed mechanically processed whole seed $(4.44 \mathrm{~g} / 100 \mathrm{~g})$ as compared with free oil $(8.39 \mathrm{~g} / 100 \mathrm{~g})$ and intact whole seed $(2.51$ $\mathrm{g} / 100 \mathrm{~g}$ ), which suggests that mechanical processing increased the extent of exposure to microbial enzymes. A similar phenomenon has been observed by Kennelly (1996). Moreover, da Silva et al. (2007) reported that
EE digestibility was $17 \%$ lower when cows were fed diets based on intact whole flax seed $(73.0 \%)$ as compared with ground flax seed $(88.4 \%)$. Finally, Oba et al. (2009) observed that apparent total-tract digestibility of cis-9,cis-12,cis-15 18:3 was about twice greater with rolled $(67.2 \%)$ as compared with intact whole flax seed $(35.2 \%)$.

\section{Experiment 4-Multivariate Factor Analysis}

The first latent factor (PC 1) is focused on milk FA profile and is more clearly associated with the equilibrium between de novo synthesis and uptake of preformed FA by the mammary gland during lipogenesis (Supplemental Figure S4; https://doi.org/10.3168/ jds.2017-12637). Positive loadings were observed for short- and medium-chain FA (from 8:0 to 16:0) in association with negative loadings for long-chain C18 FA

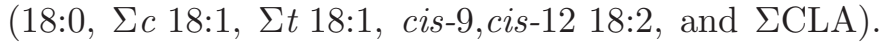
These results are in agreement with observations made in previous sections concerning the negative effect of dietary long-chain FA on de novo synthesis in the mammary gland (Palmquist et al., 1993a), a situation frequently observed in the current database. The PC 1 also appears to be related to milk protein depression often associated with dietary fat supplementation (see discussion above; DePeters and Cant, 1992; Doreau and Chilliard, 1992; Wu and Huber, 1994). In this scenario, lower milk concentrations of preformed long-chain FA (negative loadings for 18:0 and $\Sigma c$ 18:1) could be associated with increased de novo synthesis in the mammary gland (positive loadings for FA from 8:0 to 16:0) when supplemental lipids are removed from the diet, these effects being associated with a greater milk protein synthesis (positive loadings for both milk protein concentration and yield). These results are also consistent with more recent observations reported by Woolpert et al. (2016) showing that greater de novo FA is associated with increased milk protein concentration and yield in bulk tank milk from commercial dairy farms.

The PC 2 is associated with an overall increase in lactation performance (positive loadings for the yields of actual milk, milk fat, and milk protein). Negative loadings for the concentrations of milk fat and milk protein suggest a potential dilution effect associated with increased milk yield. The improved lactation performance appears to be weakly dependent on milk FA profile, when affected by dietary lipid supplements, as highlighted in PC 1 (Supplemental Figure S4; https:// doi.org/10.3168/jds.2017-12637). Strong positive loadings for milk, protein, and fat yields in PC 2 could then be related to nondietary factors such as breeds (Jersey vs. Holstein) or lactation stage. The PC 3 is associ- 
ated with the symptoms of MFD (negative loadings for milk fat concentration and yield), a situation that could be attributed to the effects of intermediates such as trans-10 18:1 and trans-10,cis-12 18:2 from incomplete biohydrogenation of dietary PUFA (potentially associated with strong positive loadings for $\Sigma t 18: 1$ and इCLA; Supplemental Figure S4; https://doi.org/10 .3168/jds.2017-12637).

The PC 4 is associated with the activity of $\Delta^{9}-$ desaturase, as positive loading factors were calculated for the FA products of this enzyme in milk fat [i.e., 14:1, 16:1, and $\Sigma c$ 18:1 (mainly cis-9 18:1)]. It should be pointed out that this PC only explains $8 \%$ of the variability. Nevertheless, a positive association was concomitantly observed with milk fat concentration of cis9,cis-12 18:2 suggesting that this situation is specific to dietary treatments with DI supplements, or to diets containing high levels of cereal concentrates, also rich in this n-6 PUFA (e.g., corn and barley; INRA-AFZ, 2002). Furthermore, cereal grains contain high levels of starch, which has been shown to increase plasma insulin in dairy cows (Oba and Allen, 2003). Ward et al. (1998) observed that insulin significantly increased the expression of the enzyme $\Delta^{9}$-desaturase in ruminants. These putative metabolic events were associated with negative loading values for milk fat concentration. In accordance with these results, Rico and Harvatine (2013) reported an increase of $\Delta^{9}$-desaturation index during the induction of MFD in dairy cows. In this context, the positive loading value for milk yield could be explained by a sparing effect of energy during MFD (Bauman et al., 2008).

The PC 5 revealed the strongest loading for milk proportion of cis-9,cis-12,cis-15 18:3, which is of particular interest from the current database built to study the effects of flax seed and oil. This positive loading could be associated with flax treatments showing the greatest efficiency of transfer of cis-9,cis-12, cis-15 18:3 from diet to milk fat. A negative loading was observed for the proportions of milk C14 (14:0 and 14:1) and C16 (16:0 and 16:1) FA. A similar phenomenon has been observed by Fauteux et al. (2016) who reported that the increase in milk cis-9,cis-12,cis-15 18:3 (+13.9 PU) observed as a result of abomasal infusion of flax oil was almost solely at the expense of 14:0 (-2.9 PU) and 16:0 $(-10.7 \mathrm{PU})$.

\section{CONCLUSIONS}

In conclusion, this meta-analysis and meta-regression revealed that supplementing flax-TRI decreased DMI and the yields of milk, fat, protein, and lactose without affecting the efficiency of utilization of dietary DM or energy as compared with nonsupplemented ISO-E diets. Of particular interest, the decrease in milk fat in response to flax-TRI supplementation was of a greater magnitude with increasing levels of corn silage in the basal diet. This information should be taken into account when formulating diets containing flax seed or oil, and perhaps other types of dietary PUFA supplements. Feeding flax-TRI increased milk fat concentration of cis-9,cis-12,cis-15 18:3 for all comparisons reported (i.e., vs. LOW-E, ISO-E, SFA, MONO, or DI). Flax-TRI also supported similar ECM as SFA, MONO, or DI supplements. As compared with flaxTRI supplements, greater milk fat concentration and feed efficiency were observed with SFA, but lower milk fat concentration and yield were obtained with DI supplements. The comparison of different forms of flax seed and oil was based on the criteria of maximizing both production performance and transfer efficiency of cis-9,cis-12,cis-15 18:3 from diet to milk fat. The analysis revealed that among the 6 categories evaluated, mechanical processing (rolling or grinding) allowed the greatest yield of ECM and the best feed efficiency. Feeding protected flax and flax hulls allowed the greatest milk fat concentrations of cis-9,cis-12,cis-15 18:3. Moreover, the greatest transfer efficiencies of this FA from diet to milk were recorded with the same 2 treatments, plus the mechanically processed whole seed. These results make this last category the most suitable treatment, among the 6 flax forms evaluated, to combine lactation performance and protection of flax constituent n-3 FA. Finally, the PC analysis was an opportunity to assess several concepts in relation with the metabolic response to dietary fat supplementation. These notions include the overall effect of dietary lipid supplements on the balance between de novo synthesis and uptake of preformed FA, and their potential negative effects on milk fat and protein concentrations.

\section{ACKNOWLEDGMENTS}

This experiment was funded through Industrial Research Chair program of the Natural Sciences and Engineering Research Council of Canada (Ottawa, ON, Canada), with industry contributions from the Dairy Farmers of Canada (Ottawa, ON, Canada), Novalait Inc. (Québec, QC, Canada), Valacta (Sainte-Anne-deBellevue, QC, Canada), Les Producteurs de Lait du Québec (Longueuil, QC, Canada), and the Ministère de l'Agriculture, des Pêcheries et de l'Alimentation du Québec (Québec, QC, Canada). The authors are also grateful to Gaétan Daigle from the Département de Mathématiques et de Statistique, Université Laval, for his assistance in statistical analyses. 


\section{REFERENCES}

AbuGhazaleh, A. A., D. J. Schingoethe, A. R. Hippen, and K. F. Kalscheur. 2003. Conjugated linoleic acid and vaccenic acid in rumen, plasma, and milk of cows fed fish oil and fats differing in saturation of 18 carbon fatty acids. J. Dairy Sci. 86:3648-3660. https://doi.org/10.3168/jds.S0022-0302(03)73970-8.

Akraim, F., M. C. Nicot, P. Juaneda, and F. Enjalbert. 2007. Conjugated linolenic acid (CLnA), conjugated linoleic acid (CLA) and other biohydrogenation intermediates in plasma and milk fat of cows fed raw or extruded linseed. Animal 1:835-843. https://doi .org/10.1017/S175173110700002X.

Allen, M. S. 2000. Effects of diet on short-term regulation of feed intake by lactating dairy cattle. J. Dairy Sci. 83:1598-1624. https:// doi.org/10.3168/jds.S0022-0302(00)75030-2.

Ambrose, D. J., J. P. Kastelic, R. Corbett, P. A. Pitney, H. V. Petit, J. A. Small, and P. Zalkovic. 2006. Lower pregnancy losses in lactating dairy cows fed a diet enriched in alpha-linolenic acid. J. Dairy Sci. 89:3066-3074. https://doi.org/10.3168/jds.S0022 -0302(06)72581-4.

Angulo, J., L. Mahecha, K. Nuernberg, G. Nuernberg, D. Dannenberger, M. Olivera, M. Boutinaud, C. Leroux, E. Albrecht, and L. Bernard. 2012. Effects of polyunsaturated fatty acids from plant oils and algae on milk fat yield and composition are associated with mammary lipogenic and SREBF1 gene expression. Animal 6:1961-1972. https://doi.org/10.1017/S1751731112000845.

Bauchart, D., F. Legay-Carmier, M. Doreau, and B. Gaillard. 1990. Lipid metabolism of liquid-associated and solid-adherent bacteria gin rumen contents of dairy cows offered lipid-supplemented diets. Br. J. Nutr. 63:563-578. https://doi.org/10.1079/BJN19900143.

Bauman, D. E., and J. M. Griinari. 2003. Nutritional regulation of milk fat synthesis. Annu. Rev. Nutr. 23:203-227. https://doi.org/ 10.1146/annurev.nutr.23.011702.073408.

Bauman, D. E., J. W. Perfield II, K. J. Harvatine, and L. H. Baumgard. 2008. Regulation of fat synthesis by conjugated linoleic acid: Lactation and the ruminant model. J. Nutr. 138:403-409.

Bell, J. A., J. M. Griinari, and J. J. Kennelly. 2006. Effect of safflower oil, flaxseed oil, monensin, and vitamin $\mathrm{E}$ on concentration of conjugated linoleic acid in bovine milk fat. J. Dairy Sci. 89:733-748. https://doi.org/10.3168/jds.S0022-0302(06)72135-X.

Benchaar, C., T. A. McAllister, H. V. Petit, and P. Y. Chouinard. 2014. Whole flax seed and flax oil supplementation of dairy cows fed high-forage or high-concentrate diets: Effects on digestion, ruminal fermentation characteristics, protozoal populations and milk fatty acid profile. Anim. Feed Sci. Technol. 198:117-129. https:// doi.org/10.1016/j.anifeedsci.2014.10.003.

Benchaar, C., G. A. Romero-Perez, P. Y. Chouinard, F. Hassanat, M. Eugene, H. V. Petit, and C. Côrtes. 2012. Supplementation of increasing amounts of linseed oil to dairy cows fed total mixed rations: Effects on digestion, ruminal fermentation characteristics, protozoal populations, and milk fatty acid composition. J. Dairy Sci. 95:4578-4590. https://doi.org/10.3168/jds.2012-5455.

Bradford, B. J., K. J. Harvatine, and M. S. Allen. 2008. Dietary unsaturated fatty acids increase plasma glucagon-like peptide-1 and cholecystokinin and may decrease premeal ghrelin in lactating dairy cows. J. Dairy Sci. 91:1443-1450. https://doi.org/10.3168/ jds.2007-0670.

Brunschwig, P., C. Hurtaud, Y. Chilliard, and F. Glasser. 2010. L'apport de lin dans la ration des vaches laitières: Effets sur la production, la composition du lait et des produits laitiers, les émissions de méthane et les performances de reproduction. INRA Prod. Anim. 23:307-318.

Brzóska, F. 2006. Effect of fatty acid calcium salts from linseed oil on the yield and n-3 fatty acid content of milk and on blood plasma parameters of cows. J. Anim. Feed Sci. 15:347-360.

Bu, D. P., J. Q. Wang, T. R. Dhiman, and S. J. Liu. 2007. Effectiveness of oils rich in linoleic and linolenic acids to enhance conjugated linoleic acid in milk from dairy cows. J. Dairy Sci. 90:998-1007. https://doi.org/10.3168/jds.S0022-0302(07)71585-0.

Caroprese, M., M. G. Ciliberti, A. Santillo, R. Marino, A. Sevi, and M. Albenzio. 2016. Immune response, productivity and quality of milk from grazing goats as affected by dietary polyunsaturated fatty acid supplementation. Res. Vet. Sci. 105:229-235. 10.1016/j. rvsc.2016.02.018.

Caroprese, M., A. Marzano, G. Entrican, S. Wattegedera, M. Albenzio, and A. Sevi. 2009. Immune response of cows fed polyunsaturated fatty acids under high ambient temperatures. J. Dairy Sci. 92:2796-2803. https://doi.org/10.3168/jds.2008-1809.

Caroprese, M., A. Marzano, R. Marino, G. Gliatta, A. Muscio, and A. Sevi. 2010. Flaxseed supplementation improves fatty acid profile of cow milk. J. Dairy Sci. 93:2580-2588. https://doi.org/10.3168/ jds.2008-2003.

Cavalieri, F. B., G. T. Santos, M. Matsushita, H. V. Petit, L. P. Rigolon, D. Silva, J. A. Horst, L. C. Capovilla, and F. S. Ramos. 2005. Milk production and milk composition of dairy cows fed Lac $100^{-3}$ or whole flaxseed. Can. J. Anim. Sci. 85:413-416. https://doi.org/ 10.4141/a04-088.

Chilliard, Y., C. Martin, J. Rouel, and M. Doreau. 2009. Milk fatty acids in dairy cows fed whole crude linseed, extruded linseed, or linseed oil, and their relationship with methane output. J. Dairy Sci. 92:5199-5211. https://doi.org/10.3168/jds.2009-2375.

Chouinard, P. Y., V. Girard, and G. J. Brisson. 1998. Fatty acid profile and physical properties of milk fat from cows fed calcium salts of fatty acids with varying instauration. J. Dairy Sci. 81:471-481. https://doi.org/10.3168/jds.S0022-0302(98)75599-7.

Collomb, M., H. Sollberger, U. Bütikofer, R. Sieber, W. Stoll, and W. Schaeren. 2004. Impact of a basal diet of hay and fodder beet supplemented with rapeseed, linseed and sunflowerseed on the fatty acid composition of milk fat. Int. Dairy J. 14:549-559. https://doi .org/10.1016/j.idairyj.2003.11.004.

Conte, G., A. Serra, P. Cremonesi, S. Chessa, B. Castiglioni, A. Cappucci, E. Bulleri, and M. Mele. 2016. Investigating mutual relationship among milk fatty acids by multivariate factor analysis in dairy cows. Livest. Sci. 188:124-132. https://doi.org/10.1016/j .livsci.2016.04.018.

Côrtes, C., D. C. da Silva-Kazama, R. Kazama, N. Gagnon, C. Benchaar, G. T. Santos, L. M. Zeoula, and H. V. Petit. 2010. Milk composition, milk fatty acid profile, digestion, and ruminal fermentation in dairy cows fed whole flaxseed and calcium salts of flaxseed oil. J. Dairy Sci. 93:3146-3157. https://doi.org/10.3168/ jds.2009-2905.

Côrtes, C., R. Kazama, D. da Silva-Kazama, C. Benchaar, L. M. Zeoula, G. T. Santos, and H. V. Petit. 2011. Digestion, milk production and milk fatty acid profile of dairy cows fed flax hulls and infused with flax oil in the abomasum. J. Dairy Res. 78:293-300. https:// doi.org/10.1017/S0022029911000446.

Côrtes, C., R. Kazama, D. da Silva-Kazama, G. T. D. Santos, L. M. Zeoula, and H. V. Petit. 2015. Composition of flaxseed recovered from the faeces of dairy cows fed different proportions of whole flaxseed in the diet. Anim. Feed Sci. Technol. 204:9-17. https:// doi.org/10.1016/j.anifeedsci.2015.03.009.

Cunnane, S. C. 2003. The contribution of $\alpha$-linolenic acid in flaxseed to human health. Pages 150-180 in Flax-The Genus Linum. A. Muir and N. Westcott, ed. Taylor and Francis, London, UK.

da Silva, D. C., G. T. Santos, A. F. Branco, J. C. Damasceno, R. Kazama, M. Matsushita, J. A. Horst, W. B. dos Santos, and H. V. Petit. 2007. Production performance and milk composition of dairy cows fed whole or ground flaxseed with or without monensin. J. Dairy Sci. 90:2928-2936. https://doi.org/10.3168/jds.2006-573.

da Silva-Kazama, D. C., C. Côrtes, R. Kazama, C. Benchaar, G. T. Santos, L. M. Zeoula, and H. V. Petit. 2011. Ruminal fermentation characteristics and fatty acid profile of ruminal fluid and milk of dairy cows fed flaxseed hulls supplemented with monensin. J. Dairy Res. 78:56-62. https://doi.org/10.1017/S0022029910000865.

Danesh Mesgaran, M., R. Jafari Jafarpoor, and S. Danesh Mesgaran. 2012. Milk production, milk fatty acid composition, and blood biochemical parameters of Holstein dairy cows fed whole or ground flaxseed instead of extruded soybeans in the first half of lactation. Iran. J. Vet. Res. 13:203-209.

Dang Van, Q. C., M. Focant, D. Deswysen, E. Mignolet, C. Turu, J. Pottier, E. Froidmont, and Y. Larondelle. 2008. Influence of an increase in diet structure on milk conjugated linoleic acid content of 
cows fed extruded linseed. Animal 2:1538-1547. https://doi.org/10 $.1017 /$ S1751731108002620.

Dang Van, Q. C., M. Focant, E. Mignolet, C. Turu, E. Froidmont, and Y. Larondelle. 2011. Influence of the diet structure on ruminal biohydrogenation and milk fatty acid composition of cows fed extruded linseed. Anim. Feed Sci. Technol. 169:1-10. https://doi .org/10.1016/j.anifeedsci.2011.05.002.

Deaville, E., D. I. Givens, and J. S. Blake. 2004. Dietary supplements of whole linseed and vitamin $\mathrm{E}$ to increase levels of alpha-linolenic acid and vitamin E in bovine milk. Anim. Res. 53:3-12. https:// doi.org/10.1051/animres:2003044.

DePeters, E. J., and J. P. Cant. 1992. Nutritional factors influencing the nitrogen composition of bovine milk: A review. J. Dairy Sci. 75:2043-2070. https://doi.org/10.3168/jds.S0022-0302(92)77964 -8 .

Doreau, M., and Y. Chilliard. 1992. Influence d'une supplémentation de la ration en lipides sur la qualité du lait chez la vache. INRA Prod. Anim. 5:103-111.

Drackley, J. K., T. H. Klusmeyer, A. M. Trusk, and J. H. Clark. 1992. Infusion of long-chain fatty acids varying in saturation and chain length into the abomasum of lactating dairy cows. J. Dairy Sci. 75:1517-1526. https://doi.org/10.3168/jds.S0022-0302(92)77908 $-9$

Egger, P., G. Holzer, S. Segato, E. Werth, F. Schwienbacher, G. Peratoner, I. Andrighetto, and A. Kasal. 2007. Effects of oilseed supplements on milk production and quality in dairy cows fed a hay-based diet. Ital. J. Anim. Sci. 6:395-405. https://doi.org/10 .4081/ijas.2007.395

Fauteux, M.-C., R. Gervais, D. E. Rico, Y. Lebeuf, and P. Y. Chouinard. 2016. Production, composition, and oxidative stability of milk highly enriched in polyunsaturated fatty acids from dairy cows fed alfalfa protein concentrate or supplemental vitamin E. J. Dairy Sci. 99:4411-4426. 10.3168/jds.2015-10722.

Ferlay, A., M. Doreau, C. Martin, and Y. Chilliard. 2013. Effects of incremental amounts of extruded linseed on the milk fatty acid composition of dairy cows receiving hay or corn silage. J. Dairy Sci. 96:6577-6595. https://doi.org/10.3168/jds.2013-6562.

Ferlay, A., B. Martin, S. Lerch, M. Gobert, P. Pradel, and Y. Chilliard. 2010. Effects of supplementation of maize silage diets with extruded linseed, vitamin E and plant extracts rich in polyphenols, and morning v. evening milking on milk fatty acid profiles in Holstein and Montbeliarde cows. Animal 4:627-640. https://doi.org/ $10.1017 /$ S1751731109991224.

Flowers, G., S. A. Ibrahim, and A. A. AbuGhazaleh. 2008. Milk fatty acid composition of grazing dairy cows when supplemented with linseed oil. J. Dairy Sci. 91:722-730. https://doi.org/10.3168/jds 2007-0410.

French, E. A., S. J. Bertics, and L. E. Armentano. 2012. Rumen and milk odd- and branched-chain fatty acid proportions are minimally influenced by ruminal volatile fatty acid infusions. J. Dairy Sci. 95:2015-2026. https://doi.org/10.3168/jds.2011-4827.

Fuentes, M. C., S. Calsamiglia, C. Sanchez, A. Gonzalez, J. R. Newbold, J. E. P. Santos, L. M. Rodriguez-Alcala, and J. Fontecha. 2008. Effect of extruded linseed on productive and reproductive performance of lactating dairy cows. Livest. Sci. 113:144-154. https://doi.org/10.1016/j.livsci.2007.03.005.

Gehanno, J. F., L. Rollin, and S. Darmoni. 2013. Is the coverage of Google Scholar enough to be used alone for systematic reviews. BMC Med. Inform. Decis. Mak. 13:7. https://doi.org/10.1186/ 1472-6947-13-7.

Glasser, F., A. Ferlay, and Y. Chilliard. 2008a. Oilseed lipid supplements and fatty acid composition of cow milk: A meta-analysis. J. Dairy Sci. 91:4687-4703. https://doi.org/10.3168/jds.2008-0987.

Glasser, F., A. Ferlay, M. Doreau, P. Schmidely, D. Sauvant, and Y. Chilliard. 2008b. Long-chain fatty acid metabolism in dairy cows: A meta-analysis of milk fatty acid yield in relation to duodenal flows and de novo synthesis. J. Dairy Sci. 91:2771-2785. https:// doi.org/10.3168/jds.2007-0383.

Gonthier, C., A. F. Mustafa, D. R. Ouellet, P. Y. Chouinard, R. Berthiaume, and H. V. Petit. 2005. Feeding micronized and extruded flaxseed to dairy cows: Effects on blood parameters and milk fatty acid composition. J. Dairy Sci. 88:748-756. https://doi.org/10 .3168/jds.S0022-0302(05)72738-7.

Goodridge, J., J. R. Ingalls, and G. H. Crow. 2001. Transfer of omega-3 linolenic acid and linoleic acid to milk fat from flaxseed or Linola protected with formaldehyde. Can. J. Anim. Sci. 81:525532. https://doi.org/10.4141/a01-024.

Hawkins, A., K. Yuan, C. K. Armendariz, G. Highland, N. M. Bello, T. Winowiski, J. S. Drouillard, E. C. Titgemeyer, and B. J. Bradford. 2013. Effects of urea formaldehyde condensation polymer treatment of flaxseed on ruminal digestion and lactation in dairy cows. J. Dairy Sci. 96:3907-3915. https://doi.org/10.3168/jds.2012 $-6207$.

He, M., and L. E. Armentano. 2011. Effect of fatty acid profile in vegetable oils and antioxidant supplementation on dairy cattle performance and milk fat depression. J. Dairy Sci. 94:2481-2491. https://doi.org/10.3168/jds.2010-3755.

Hosseinian, F. S., and T. Beta. 2009. Patented techniques for the extraction and isolation of secoisolariciresinol diglucoside from flaxseed. Recent Pat. Food Nutr. Agric. 1:25-31.

Hurtaud, C., G. Chesneau, D. Coulmier, and J. L. Peyraud. 2013a. Effects of extruded linseed or alfalfa protein concentrate in interaction with two levels of concentrates on milk production and composition in dairy cows. Livest. Sci. 158:64-73. https://doi.org/ 10.1016/j.livsci.2013.10.002.

Hurtaud, C., M. Dutreuil, M. Coppa, C. Agabriel, and B. Martin. 2013b. Characterization of milk from feeding systems based on herbage or corn silage with or without flaxseed and authentication through fatty acid profile. Dairy Sci. Technol. 94:103-123. https:// doi.org/10.1007/s13594-013-0147-0.

Hurtaud, C., F. Faucon, S. Couvreur, and J. L. Peyraud. 2010. Linear relationship between increasing amounts of extruded linseed in dairy cow diet and milk fatty acid composition and butter properties. J. Dairy Sci. 93:1429-1443. https://doi.org/10.3168/jds.2009 $-2839$.

INRA-AFZ (Institut National de la Recherche Agronomique-Association Française de Zootechnie). 2002. Tables de composition et de valeur nutritive des matières premières destinées aux animaux d'élevage. D. Sauvant, J.-M. Perez, and G. Tran, coord. INRA Editions, Versailles, France.

Jenkins, T. C. 1993. Lipid metabolism in the rumen. J. Dairy Sci. 76:3851-3863. https://doi.org/10.3168/jds.S0022-0302(93)77727 $-9$.

Kaiser, H. F. 1960. The application of electronic computers to factor analysis. Educ. Psychol. Meas. 20:141-151. https://doi.org/10 $.1177 / 001316446002000116$.

Kelly, M. L., J. R. Berry, D. A. Dwyer, J. M. Griinari, P. Y. Chouinard, M. E. Van Amburgh, and D. E. Bauman. 1998. Dietary fatty acid sources affect conjugated linoleic acid concentrations in milk from lactating dairy cows. J. Nutr. 128:881-885.

Kennelly, J. J. 1996. The fatty acid composition of milk fat as influenced by feeding oilseeds. Anim. Feed Sci. Technol. 60:137-152. https://doi.org/10.1016/0377-8401(96)00973-X.

Kliem, K. E., P. C. Aikman, D. J. Humphries, R. Morgan, K. J. Shingfield, and D. I. Givens. 2009. Effect of replacing calcium salts of palm oil distillate with extruded linseeds on milk fatty acid composition in Jersey and Holstein cows. Animal 3:1754-1762. https:// doi.org/10.1017/S1751731109990723.

Kudrna, V., and M. Marounek. 2008. Influence of feeding whole sunflower seed and extruded linseed on production of dairy cows, rumen and plasma constituents, and fatty acid composition of milk. Arch. Anim. Nutr. 62:60-69. https://doi.org/10.1080/ 17450390701780243.

Lee, Y. J., and T. C. Jenkins. 2011. Biohydrogenation of linolenic acid to stearic acid by the rumen microbial population yields multiple intermediate conjugated diene isomers. J. Nutr. 141:1445-1450. https://doi.org/10.3945/jn.111.138396.

Lerch, S., A. Ferlay, K. J. Shingfield, B. Martin, D. Pomiès, and Y. Chilliard. 2012. Rapeseed or linseed supplements in grass-based diets: Effects on milk fatty acid composition of Holstein cows over two consecutive lactations. J. Dairy Sci. 95:5221-5241. https://doi .org/10.3168/jds.2012-5337. 
Liu, Z. L., D. P. Yang, P. Chen, S. B. Lin, X. Y. Jiang, W. Zhao, J. M. Li, and W. X. Dong. 2008. Effect of dietary sources of roasted oilseeds on blood parameters and milk fatty acid composition. Czech J. Anim. Sci. 53:219-226.

Livingstone, K. M., D. J. Humphries, P. Kirton, K. E. Kliem, D. I. Givens, and C. K. Reynolds. 2015. Effects of forage type and extruded linseed supplementation on methane production and milk fatty acid composition of lactating dairy cows. J. Dairy Sci. 98:4000-4011. https://doi.org/10.3168/jds.2014-8987.

Loor, J. J., A. Ferlay, A. Ollier, M. Doreau, and Y. Chilliard. 2005a. Relationship among trans and conjugated fatty acids and bovine milk fat yield due to dietary concentrate and linseed oil. J. Dairy Sci. 88:726-740. https://doi.org/10.3168/jds.S0022-0302(05)72736 -3 .

Loor, J. J., A. Ferlay, A. Ollier, K. Ueda, M. Doreau, and Y. Chilliard. 2005b. High-concentrate diets and polyunsaturated oils alter trans and conjugated isomers in bovine rumen, blood, and milk. J. Dairy Sci. 88:3986-3999. https://doi.org/10.3168/jds.S0022 $-0302(05) 73085-X$.

Mach, N., R. L. Zom, H. C. Widjaja, P. G. van Wikselaar, R. E. Weurding, R. M. Goselink, J. van Baal, M. A. Smits, and A. M. van Vuuren. 2013. Dietary effects of linseed on fatty acid composition of milk and on liver, adipose and mammary gland metabolism of periparturient dairy cows. J. Anim. Physiol. Anim. Nutr. (Berl.) 97:89-104. https://doi.org/10.1111/jpn.12042.

Madsen, T. G., M. O. Nielsen, J. B. Andersen, and K. L. Ingvartsen. 2008. Continuous lactation in dairy cows: Effect on milk production and mammary nutrient supply and extraction. J. Dairy Sci. 91:1791-1801. https://doi.org/10.3168/jds.2007-0905.

Malpuech-Brugère, C., J. Mouriot, C. Boue-Vaysse, N. Combe, J. L. Peyraud, P. LeRuyet, G. Chesneau, B. Morio, and J. M. Chardigny. 2010. Differential impact of milk fatty acid profiles on cardiovascular risk biomarkers in healthy men and women. Eur. J. Clin. Nutr. 64:752-759. https://doi.org/10.1038/ejcn.2010.73.

Mannai, H., É. Charbonneau, L. Fadul-Pacheco, D. Pellerin, and P. Y. Chouinard. 2016. An appraisal of the concept of Rumen Unsaturated Fatty Acid Load and its relation to milk fat concentration using data from commercial dairy farms. Prof. Anim. Sci. 32:665-671. https://doi.org/10.15232/pas.2016-01526.

Meignan, T., C. Lechartier, G. Chesneau, and N. Bareille. 2017. Effects of feeding extruded linseed on production performance and milk fatty acid profile in dairy cows: A meta-analysis. J. Dairy Sci. 100:4394-4408. https://doi.org/10.3168/jds.2016-11850.

Moallem, U. 2009. The effects of extruded flaxseed supplementation to high-yielding dairy cows on milk production and milk fatty acid composition. Anim. Feed Sci. Technol. 152:232-242. https://doi .org/10.1016/j.anifeedsci.2009.04.018.

Mohammed, R., S. M. McGinn, and K. A. Beauchemin. 2011. Prediction of enteric methane output from milk fatty acid concentrations and rumen fermentation parameters in dairy cows fed sunflower, flax, or canola seeds. J. Dairy Sci. 94:6057-6068. https://doi.org/ 10.3168/jds.2011-4369.

Moore, J. H., and W. W. Christie. 1979. Lipid metabolism in the mammary gland of ruminant animals. Prog. Lipid Res. 17:347395. https://doi.org/10.1016/0079-6832(79)90012-0.

Mosley, E. E., G. L. Powell, M. B. Riley, and T. C. Jenkins. 2002. Microbial biohydrogenation of oleic acid to trans isomers in vitro. J. Lipid Res. 43:290-296.

Mustafa, A. F., P. Y. Chouinard, and D. A. Christensen. 2003. Effects of feeding micronised flaxseed on yield and composition of milk from Holstein cows. J. Sci. Food Agric. 83:920-926. https://doi .org/10.1002/jsfa. 1430 .

Mutsvangwa, T., M. R. Hobin, and G. N. Gozho. 2012. Effects of method of barley grain processing and source of supplemental dietary fat on duodenal nutrient flows, milk fatty acid profiles, and microbial protein synthesis in dairy cows. J. Dairy Sci. 95:59615977. https://doi.org/10.3168/jds.2012-5491.

NRC. 2001. Nutrient Requirements of Dairy Cattle. 7th rev. ed. Natl. Acad. Press, Washington, DC.

Neveu, C., B. Baurhoo, and A. Mustafa. 2013. Effect of feeding extruded flaxseed with different forage: concentrate ratios on the performance of dairy cows. J. Dairy Sci. 96:3886-3894. https://doi .org/10.3168/jds.2012-6189.

Neveu, C., B. Baurhoo, and A. Mustafa. 2014. Effect of feeding extruded flaxseed with different grains on the performance of dairy cows and milk fatty acid profile. J. Dairy Sci. 97:1543-1551. https://doi .org/10.3168/jds.2013-6728.

Oba, M., and M. S. Allen. 2003. Effects of corn grain conservation method on feeding behavior and productivity of lactating dairy cows at two dietary starch concentrations. J. Dairy Sci. 86:174183. https://doi.org/10.3168/jds.S0022-0302(03)73598-X.

Oba, M., G. Thangavelu, M. Dehghan-Banadaky, and D. J. Ambrose. 2009. Unprocessed whole flaxseed is as effective as dry-rolled flaxseed at increasing $\alpha$-linolenic acid concentration in milk of dairy cows. Livest. Sci. 122:73-76. https://doi.org/10.1016/j.livsci.2008 .07 .012 .

Oeffner, S. P., Y. Qu, J. Just, N. Quezada, E. Ramsing, M. Keller, G. Cherian, L. Goddick, and G. Bobe. 2013. Effect of flaxseed supplementation rate and processing on the production, fatty acid profile, and texture of milk, butter, and cheese. J. Dairy Sci. 96:1177-1188. https://doi.org/10.3168/jds.2012-5941.

Palin, M. F., C. Côrtes, C. Benchaar, P. Lacasse, and H. V. Petit. 2014. mRNA Expression of lipogenic enzymes in mammary tissue and fatty acid profile in milk of dairy cows fed flax hulls and infused with flax oil in the abomasum. Br. J. Nutr. 111:1011-1020. https://doi.org/10.1017/S0007114513003589.

Palmquist, D. L., D. A. Beaulieu, and D. M. Barbano. 1993a. Feed and animal factors influencing milk fat composition. J. Dairy Sci. 76:1753-1771. https://doi.org/10.3168/jds.S0022-0302(93)77508 -6 .

Palmquist, D. L., and T. C. Jenkins. 1980. Fat in lactation rations. J. Dairy Sci. 63:1-14. https://doi.org/10.3168/jds.S0022 -0302(80)82881-5 (Review).

Palmquist, D. L., M. R. Weisbjerg, and T. Hvelplund. 1993b. Ruminal, intestinal, and total digestibilities of nutrients in cows fed diets high in fat and undegradable protein. J. Dairy Sci. 76:13531364. https://doi.org/10.3168/jds.S0022-0302(93)77466-4.

Petit, H. V. 2002. Digestion, milk production, milk composition, and blood composition of dairy cows fed whole flaxseed. J. Dairy Sci. 85:1482-1490. https://doi.org/10.3168/jds.S0022-0302(02)74217 -3 .

Petit, H. V. 2003. Digestion, milk production, milk composition, and blood composition of dairy cows fed formaldehyde treated flaxseed or sunflower seed. J. Dairy Sci. 86:2637-2646. https://doi.org/10 .3168/jds.S0022-0302(03)73859-4.

Petit, H. V. 2010. Review: Feed intake, milk production and milk composition of dairy cows fed flaxseed. Can. J. Anim. Sci. 90:115-127. https://doi.org/10.4141/cjas09040.

Petit, H. V. 2015. Milk production and composition, milk fatty acid profile, and blood composition of dairy cows fed different proportions of whole flaxseed in the first half of lactation. Anim. Feed Sci. Technol. 205:23-30. https://doi.org/10.1016/j.anifeedsci.2015 .04 .009 .

Petit, H. V., and C. Benchaar. 2007. Milk production, milk composition, blood composition, and conception rate of transition dairy cows fed different profiles of fatty acids. Can. J. Anim. Sci. 87:591600. https://doi.org/10.4141/cjas07027.

Petit, H. V., and C. Côrtes. 2010. Milk production and composition, milk fatty acid profile, and blood composition of dairy cows fed whole or ground flaxseed in the first half of lactation. Anim. Feed Sci. Technol. 158:36-43. https://doi.org/10.1016/j.anifeedsci.2010 .03.013.

Petit, H. V., R. J. Dewhurst, N. D. Scollan, J. G. Proulx, M. Khalid, W. Haresign, H. Twagiramungu, and G. E. Mann. 2002. Milk production and composition, ovarian function, and prostaglandin secretion of dairy cows fed omega-3 fats. J. Dairy Sci. 85:889-899. https://doi.org/10.3168/jds.S0022-0302(02)74147-7.

Petit, H. V., and N. Gagnon. 2009. Concentration of the mammalian lignans enterolactone and enterodiol in milk of cows fed diets containing different concentrations of whole flaxseed. Animal 3:14281435. https://doi.org/10.1017/S1751731109990346. 
Petit, H. V., and N. Gagnon. 2011. Production performance and milk composition of dairy cows fed different concentrations of flax hulls. Anim. Feed Sci. Technol. 169:46-52. https://doi.org/10.1016/j .anifeedsci.2011.05.008.

Petit, H. V., N. Gagnon, P. S. Mir, R. Cao, and S. Cui. 2009. Milk concentration of the mammalian lignan enterolactone, milk production, milk fatty acid profile, and digestibility in dairy cows fed diets containing whole flaxseed or flaxseed meal. J. Dairy Res. 76:257-264. https://doi.org/10.1017/S0022029909003999.

Petit, H. V., C. Germiquet, and D. Lebel. 2004. Effect of feeding whole, unprocessed sunflower seeds and flaxseed on milk production, milk composition, and prostaglandin secretion in dairy cows. J. Dairy Sci. 87:3889-3898. https://doi.org/10.3168/jds.S0022 $-0302(04) 73528-6$.

Petit, H. V., M. Ivan, and P. S. Mir. 2005. Effects of flaxseed on protein requirements and $\mathrm{N}$ excretion of dairy cows fed diets with two protein concentrations. J. Dairy Sci. 88:1755-1764. https://doi .org/10.3168/jds.S0022-0302(05)72850-2.

Petit, H. V., M. F. Palin, and L. Doepel. 2007. Hepatic lipid metabolism in transition dairy cows fed flaxseed. J. Dairy Sci. 90:47804792. https://doi.org/10.3168/jds.2007-0066.

Rego, O. A., S. P. Alves, L. M. Antunes, H. J. Rosa, C. F. Alfaia, J. A. Prates, A. R. Cabrita, A. J. Fonseca, and R. J. Bessa. 2009. Rumen biohydrogenation-derived fatty acids in milk fat from grazing dairy cows supplemented with rapeseed, sunflower, or linseed oils. J. Dairy Sci. 92:4530-4540. https://doi.org/10.3168/jds.2009 -2060 .

Resende, T. L., J. Kraft, K. J. Soder, A. B. Pereira, D. E. Woitschach, R. B. Reis, and A. F. Brito. 2015. Incremental amounts of ground flaxseed decrease milk yield but increase n- 3 fatty acids and conjugated linoleic acids in dairy cows fed high-forage diets. J. Dairy Sci. 98:4785-4799. https://doi.org/10.3168/jds.2014-9115.

Rico, D. E., and K. J. Harvatine. 2013. Induction of and recovery from milk fat depression occurs progressively in dairy cows switched between diets that differ in fiber and oil concentration. J. Dairy Sci. 96:6621-6630. https://doi.org/10.3168/jds.2013-6820.

Saliba, L., R. Gervais, Y. Lebeuf, and P. Y. Chouinard. 2014. Effect of feeding linseed oil in diets differing in forage to concentrate ratio: 1. Production performance and milk fat content of biohydrogenation intermediates of alpha-linolenic acid. J. Dairy Res. 81:82-90. https://doi.org/10.1017/S0022029913000691.

Santos, J. E. P., T. R. Bilby, W. W. Thatcher, C. R. Staples, and F. T. Silvestre. 2008. Long chain fatty acids of diet as factors influencing reproduction in cattle. Reprod. Domest. Anim. 43(Suppl. 2):23-30. https://doi.org/10.1111/j.1439-0531.2008.01139.x.

Sauvant, D., P. Schmidely, J. J. Daudin, and N. R. St-Pierre. 2008. Meta-analyses of experimental data in animal nutrition. Animal 2:1203-1214. https://doi.org/10.1017/S1751731108002280.

Secchiari, P., M. Antongiovanni, M. Mele, A. Serra, A. Buccioni, G. Ferruzzi, F. Paoletti, and F. Petacchi. 2003. Effect of kind of dietary fat on the quality of milk fat from Italian Friesian cows. Livest. Prod. Sci. 83:43-52. https://doi.org/10.1016/s0301 $-6226(03) 00043-5$.

Shingfield, K. J., L. Bernard, C. Leroux, and Y. Chilliard. 2010. Role of trans fatty acids in the nutritional regulation of mammary lipogenesis in ruminants. Animal 4:1140-1166. https://doi.org/10 $.1017 /$ S1751731110000510.

Sokal, R. R., and F. J. Rohlf. 1995. Biometry: The Principles and Practice of Statistics in Biological Research. W.H. Freeman and Company, New York, NY.

Stergiadis, S., C. Leifert, C. J. Seal, M. D. Eyre, H. Steinshamn, and G. Butler. 2014. Improving the fatty acid profile of winter milk from housed cows with contrasting feeding regimes by oilseed supplementation. Food Chem. 164:293-300. https://doi.org/10.1016/ j.foodchem.2014.05.021.

Sterk, A., B. E. Johansson, H. Z. Taweel, M. Murphy, A. M. van Vuuren, W. H. Hendriks, and J. Dijkstra. 2011. Effects of forage type, forage to concentrate ratio, and crushed linseed supplemen- tation on milk fatty acid profile in lactating dairy cows. J. Dairy Sci. 94:6078-6091. https://doi.org/10.3168/jds.2011-4617.

Sterk, A., A. M. Van Vuuren, W. H. Hendriks, and J. Dijkstra. 2012. Effects of different fat sources, technological forms and characteristics of the basal diet on milk fatty acid profile in lactating dairy cows: A meta-analysis. J. Agric. Sci. 150:495-517. https://doi.org/ $10.1017 / \mathrm{s} 0021859611000979$.

Sterk, A., B. Vlaeminck, A. M. van Vuuren, W. H. Hendriks, and J. Dijkstra. 2012. Effects of feeding different linseed sources on omasal fatty acid flows and fatty acid profiles of plasma and milk fat in lactating dairy cows. J. Dairy Sci. 95:3149-3165. https://doi.org/ $10.3168 /$ jds.2011-4474.

Sultana, H., T. Ishida, T. Shintaku, S. Kanda, and H. Itabashi. 2008. Effect of feeding Ca-salts of fatty acids from soybean oil and linseed oil on c9,t11-CLA production in ruminal fluid and milk of Holstein dairy cows. Asian-australas. J. Anim. Sci. 21:1262-1270. https://doi.org/10.5713/ajas.2008.60730.

Thangavelu, G., M. G. Colazo, D. J. Ambrose, M. Oba, E. K. Okine, and M. K. Dyck. 2007. Diets enriched in unsaturated fatty acids enhance early embryonic development in lactating Holstein cows. Theriogenology 68:949-957. https://doi.org/10.1016/j .theriogenology.2007.07.002.

Thanh, L. P., and W. Suksombat. 2015. Milk yield, composition, and fatty acid profile in dairy cows fed a high-concentrate diet blended with oil mixtures rich in polyunsaturated fatty acids. Asian-australas. J. Anim. Sci. 28:796-806. https://doi.org/10.5713/ajas.14 .0810 .

Vlaeminck, B., V. Fievez, A. R. J. Cabrita, A. J. M. Fonseca, and R. J. Dewhurst. 2006. Factors affecting odd- and branched-chain fatty acids in milk: A review. Anim. Feed Sci. Technol. 131:389-417. https://doi.org/10.1016/j.anifeedsci.2006.06.017.

Ward, A. T., K. M. Wittenberg, and R. Przybylski. 2002. Bovine milk fatty acid profiles produced by feeding diets containing solin, flax and canola. J. Dairy Sci. 85:1191-1196. https://doi.org/10.3168/ jds.S0022-0302(02)74182-9.

Ward, R. J., M. T. Travers, S. E. Richards, R. G. Vernon, A. M. Salter, P. J. Buttery, and M. C. Barber. 1998. Stearoyl-CoA desaturase mRNA is transcribed from a single gene in the ovine genome. Biochim. Biophys. Acta. Lipids and Lipid Metabolism 1391:145-156. https://doi.org/10.1016/S0005-2760(97)00210-5.

Weill, P., B. Schmitt, G. Chesneau, N. Daniel, F. Safraou, and P. Legrand. 2002. Effects of introducing linseed in livestock diet on blood fatty acid composition of consumers of animal products. Ann. Nutr. Metab. 46:182-191.

Woolpert, M. E., H. M. Dann, K. W. Cotanch, C. Melilli, L. E. Chase, R. J. Grant, and D. M. Barbano. 2016. Management, nutrition, and lactation performance are related to bulk tank milk de novo fatty acid concentration on Northeastern US dairy farms. J. Dairy Sci. 99:8486-8497. https://doi.org/10.3168/jds.2016-10998.

Wu, Z., and J. T. Huber. 1994. Relationship between dietary fat supplementation and milk protein concentration in lactating cows: A review. Livest. Prod. Sci. 39:141-155. https://doi.org/10.1016/ 0301-6226(94)90180-5.

Ye, J. A., C. Wang, H. F. Wang, H. W. Ye, B. X. Wang, H. Y. Liu, Y. M. Wang, Z. Q. Yang, and J. X. Liu. 2009. Milk production and fatty acid profile of dairy cows supplemented with flaxseed oil, soybean oil, or extruded soybeans. Acta Agric. Scand. Anim. Sci. 59:121-129. https://doi.org/10.1080/09064700903082252.

Zachut, M., A. Arieli, H. Lehrer, L. Livshitz, S. Yakoby, and U. Moallem. 2010a. Effects of increased supplementation of $n-3$ fatty acids to transition dairy cows on performance and fatty acid profile in plasma, adipose tissue, and milk fat. J. Dairy Sci. 93:5877-5889. https://doi.org/10.3168/jds.2010-3427.

Zachut, M., I. Dekel, H. Lehrer, A. Arieli, A. Arav, L. Livshitz, S. Yakoby, and U. Moallem. 2010b. Effects of dietary fats differing in n-6:n-3 ratio fed to high-yielding dairy cows on fatty acid composition of ovarian compartments, follicular status, and oocyte quality. J. Dairy Sci. 93:529-545. https://doi.org/10.3168/jds.2009-2167. 